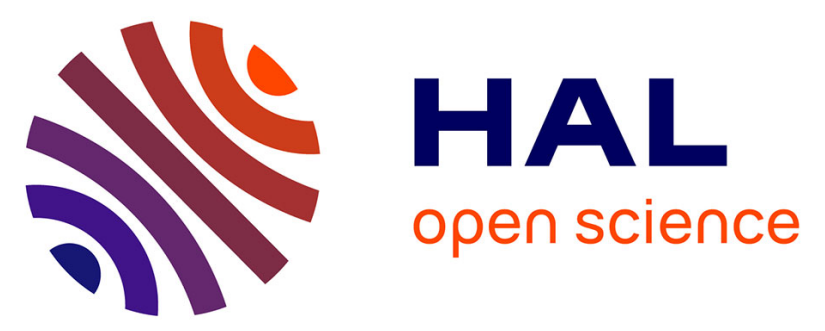

\title{
Inferences on the Mesozoic evolution of the North Aegean from the isotopic record of the Chalkidiki block
}

Konstantinos Kydonakis, Marc Poujol, Patrick Monie, Elias

Chatzitheodoridis, Jean-Pierre Brun

\section{- To cite this version:}

Konstantinos Kydonakis, Marc Poujol, Patrick Monie, Elias Chatzitheodoridis, Jean-Pierre Brun. Inferences on the Mesozoic evolution of the North Aegean from the isotopic record of the Chalkidiki block. Tectonophysics, 2016, 682, pp.65-84. 10.1016/j.tecto.2016.06.006 . insu-01329472

\section{HAL Id: insu-01329472 https://hal-insu.archives-ouvertes.fr/insu-01329472}

Submitted on 9 Jun 2016

HAL is a multi-disciplinary open access archive for the deposit and dissemination of scientific research documents, whether they are published or not. The documents may come from teaching and research institutions in France or abroad, or from public or private research centers.
L'archive ouverte pluridisciplinaire HAL, est destinée au dépôt et à la diffusion de documents scientifiques de niveau recherche, publiés ou non, émanant des établissements d'enseignement et de recherche français ou étrangers, des laboratoires publics ou privés. 


\section{Accepted Manuscript}

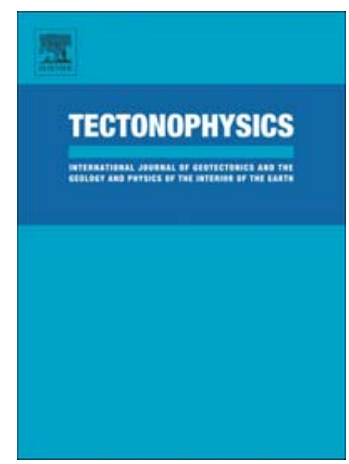

Inferences on the Mesozoic evolution of the North Aegean from the isotopic record of the Chalkidiki block

Konstantinos Kydonakis, Jean-Pierre Brun, Marc Poujol, Patrick Monié, Elias Chatzitheodoridis

PII:

S0040-1951(16)30212-8

DOI:

doi: $10.1016 /$ j.tecto.2016.06.006

Reference: $\quad$ TECTO 127144

To appear in: $\quad$ Tectonophysics

Received date: 6 January 2016

Revised date: $\quad 1$ June 2016

Accepted date: $\quad 2$ June 2016

Please cite this article as: Kydonakis, Konstantinos, Brun, Jean-Pierre, Poujol, Marc, Monié, Patrick, Chatzitheodoridis, Elias, Inferences on the Mesozoic evolution of the North Aegean from the isotopic record of the Chalkidiki block, Tectonophysics (2016), doi: $10.1016 /$ j.tecto.2016.06.006

This is a PDF file of an unedited manuscript that has been accepted for publication. As a service to our customers we are providing this early version of the manuscript. The manuscript will undergo copyediting, typesetting, and review of the resulting proof before it is published in its final form. Please note that during the production process errors may be discovered which could affect the content, and all legal disclaimers that apply to the journal pertain. 


\section{Inferences on the Mesozoic evolution of the North Aegean from the isotopic record of the Chalkidiki block}

Konstantinos Kydonakis ${ }^{a}$, Jean-Pierre Brun ${ }^{\mathrm{a}}$, Marc Poujol ${ }^{\mathrm{a}}$, Patrick Monié ${ }^{\mathrm{b}}$, Elias Chatzitheodoridis $^{\mathrm{c}}$

${ }^{a}$ Géosciences Rennes, UMR CNRS 6118, Université Rennes1, OSUR, 35042 Rennes, France

${ }^{\mathrm{b}}$ Géosciences Montpellier, UMR 5243 CNRS, Université Montpellier2, place E. Bataillon, 34095 Montpellier, France

${ }^{\mathrm{c}}$ National Technical University of Athens, School of Mining and Metallurgical Engineering, Department of Geological Sciences, Laboratory of Mineralogy, Petrology and Economic Geology, Greece

Corresponding author: Konstantinos Kydonakis, Géosciences Rennes UMR 6118, Université Rennes 1, Campus de Beaulieu, 35042 Rennes, France (konstantinos.kydonakis@ gmail.com) 


\section{Highlights}

We present new geochronology data from the southwestern part of the Rhodope

The study area (Chalkidiki block) retains a rather rich Cretaceous isotopic record

Monazite breakdown at $\sim 132$ Ma provides a minimum age for the amphibolite-facies event

Amphibolite-facies overprint predates the end of thrusting in the area

Cooling and arrival at shallow crustal levels occurred by the end of Early Cretaceous 


\section{ABSTRACT}

The Chalkidiki block is a major domain in the North Aegean that, contrary to other domains in the region, largely escaped thermal perturbations during Tertiary extension. As a result, the Chalkidiki block is an ideal candidate to glean information related to the timing of Mesozoic thermal events using appropriate geochronological techniques. We have undertaken a laser ablation inductively coupled plasma mass spectrometry (LA-ICP-MS) study (U-Th-Pb on monazites and U-Pb on zircons) coupled with ${ }^{40} \mathrm{Ar} /{ }^{39} \mathrm{Ar}$ dating on nine samples from various structural levels within the thrust system of the Chalkidiki block. The eastern, and structurally lower part of the system revealed a complete isotopic reset of Carboniferous - Early Triassic monazites coeval with partial monazite destruction, REE-mobilisation and formation of apatiteallanite-epidote coronas at $\sim 132 \mathrm{Ma}$, a reaction that is commonly observed in amphibolite-facies rocks. These coronas formed after crystallisation of garnet (i.e., at $\mathrm{T}>580^{\circ} \mathrm{C}$ ) and, in all probability, either close to the peak-temperature conditions $\left(\sim 620^{\circ} \mathrm{C}\right)$ on a prograde path or during retrogression between the peak-temperature and the low-temperature boundary of the amphibolite facies. Cooling of these rocks and arrival at mid-crustal levels occurred at 95-100 Ma. By contrast, the western, and structurally uppermost part of the system went through the same event by 120-125 Ma. Further structural considerations with respect to mediumtemperature geochronology data imply that syn-metamorphic thrusting must have ceased by early Late Cretaceous. We emphasize that, with the sole exception of the Chalkidiki block, no pre-45 Ma medium-temperature geochronology data are preserved in other North Aegean domains, a feature that is clearly related to the extension-induced thermal perturbation of the region during the Tertiary. 
Keywords: Aegean, Rhodope, monazite, micas, Ar/Ar, U-Th- $\mathrm{Pb}$

\section{Introduction}

The Hellenic Thrust Wedge resulted from the Mesozoic to Early Cenozoic Eurasia-Africa convergence manifested by (i) the southward-verging accretion of three continental blocks (van Hinsbergen et al., 2005), namely, from top to base, the Rhodopia, Pelagonia and the External Hellenides, and (ii) the closure of two intervening oceanic domains along the two suture zones of Vardar-Axios and Pindos (Robertson, 2002; Papanikolaou, 2009; 2013) (Fig.1). Extensional inversion of the Hellenic Thrust Wedge that initiated in Early Cenozoic corresponds to gravity spreading with a rate controlled by the velocity of the trench retreat (Gautier et al., 1999; Jolivet and Faccenna, 2000; Brun and Sokoutis, 2010; Jolivet and Brun, 2010; Kydonakis et al., 2015a; Brun et al., 2016).

The Mesozoic convergence history has received significant attention leading to regional considerations for the hinterland of the Hellenic Thrust Wedgecollectively known as the Rhodope (Burg et al., 1990; 1996; Ricou et al., 1998). Following the discussion in Kydonakis et al. (2015a), the Rhodope can be divided into three distinct domains that are, from northeast to southwest, the Northern Rhodope Domain, the Southern Rhodope Core Complex and the Chalkidiki block (Fig.2). The Northern Rhodope Domain and the Chalkidiki block arguably participated in the same Mesozoic metamorphic event(s) experiencing, however, different tectono-thermal histories whereas the Southern Rhodope Core Complex (and the time-equivalent Northern Rhodope Core Complex) developed exclusively during the Middle Eocene-Miocene Aegean extension (see Kydonakis et al., 2015b and discussion therein). 
The exact timing of these metamorphic event(s) in the north Rhodope is often accessed by geochronology studies (e.g., Reischmann and Kostopoulos, 2002; Liati et al., 2011) the results of which are commonly tested against regional structural analysis (e.g., Ricou et al., 1998; Krenn et al., 2010). Although the peak eclogite-facies metamorphic event is generally accepted as being Jurassic in age, with some controversy involved (see Burg et al., 2012; and references therein), the post-peak thermal history is not explicitly constrained with respect to the Mesozoic cooling. This is likely due to (i) extensive reworking during the Cenozoic extension coeval with gneiss domes formation, widespread igneous activity and the related high thermal gradient and (ii) absence of application of medium-temperature geochronology methods on non-affected lithologies within appropriate domains. In fact, medium-temperature geochronology data $\left({ }^{40} \mathrm{Ar} /{ }^{39} \mathrm{Ar}\right.$ on micas) point mostly toward an Eocene - Miocene age which can be only linked to the Tertiary extension (e.g., Lips et al., 2000; Bonev et al., 2013). The Chalkidiki block, the southern domain of the Rhodope, largely escaped the thermal effects of the Tertiary extension and, therefore, constitute an ideal candidate to define the Mesozoic post-peak metamorphic evolution in the North Aegean.

In this contribution we present new ${ }^{40} \mathrm{Ar} /{ }^{39} \mathrm{Ar}$ (micas) and LA-ICP-MS (monazite and zircon) ages from the Chalkidiki block. Our results are analysed and interpreted under three complementary perspectives: (i) the timing of the regional amphibolite-facies metamorphism as well as the post-peak thermal cooling, (ii) the end of syn-metamorphic thrusting and (iii) the significance of tectonic/metamorphic events recorded at the scale of the Rhodope Metamorphic Province.

\section{Geological setting}




\subsection{The Rhodope Metamorphic Province}

The Rhodope Metamorphic Province, or simply the Rhodope, constitutes the hinterland of the Hellenides (northeast Greece - southwest Bulgaria) and is considered an as area of largescale nappe tectonics that recorded the Mesozoic convergence-related deformation of the Aegean (e.g., Burg et al., 1990; 1996; Ricou et al., 1998; Krenn et al., 2010; Jahn-Awe et al., 2010; Nagel et al., 2011; Burg, 2012; and references therein) (Fig.2). The Rhodope can be described as a Mesozoic southwestward verging crustal-scale pile of syn-metamorphic thrust units (Burg et al., 1996; Ricou et al., 1998) strongly affected by Cenozoic extension of core complex type (Dinter and Royden, 1993; Sokoutis et al., 1993; Bonev et al., 2006; Brun and Sokoutis, 2007) and syn- to post-extension magmatism (e.g., Kolocotroni and Dixon, 1991; Jones et al., 1992; Marchev et al., 2004, 2013). It is bordered to the north by the Maritza dextral strike-slip fault, to the east by the Middle Eocene to Quaternary Thrace Basin, to the west by the Vardar-Axios Thermaikos basin that roughly correlate with the Vardar Suture Zone and to the south by the North Aegean Trough. Following Kydonakis et al. (2015a), we recognise three major domains in the Rhodope that are, from northeast to southwest: (i) the Northern Rhodope Domain, (ii) the Northern and Southern Rhodope Core Complexes, and (iii) the Chalkidiki block (Fig.2).

The Northern Rhodope Domain (NRD) is the northeastern part of the Rhodope and represents an imbricate system mostly made of high-grade metamorphic rocks including a former Upper Jurassic magmatic arc (Fig.2). Orthogneisses, mafic eclogites and amphibolites, paragneisses, scarce marble horizons and ultramafics appear within the NRD (e.g., Mposkos and Liati, 1993; Liati and Seidel, 1996; Turpaud and Reischmann, 2010; Janák et al., 2011). 
Although upper amphibolite-facies metamorphic rocks are widespread, many occurrences of variably retrogressed eclogites that preserve evidence of an older high-pressure (HP) phase have been reported (e.g., Burg, 2012; Moulas et al., 2013 and references therein). Micro-diamond inclusions in metapelites attest for the existence of an ultrahigh-pressure (UHP) event that indicates a minimum local pressure of 3.0 GPa (for $600{ }^{\circ} \mathrm{C}$ ) (Mposkos and Kostopoulos, 2001; Perraki et al., 2006; Schmidt et al., 2010). Jurassic and Cretaceous zircon/monazite metamorphic ages from both garnet-kyanite gneisses and amphibolitised eclogites have been reported in the literature (Reischmann and Kostopoulos, 2002; Bauer et al., 2007; Hoinkes et al., 2008; Bosse et al., 2010; Krenn et al., 2010; Liati et al., 2011; Didier et al., 2014). Metamorphic conditions are estimated at $1.9 \mathrm{GPa} / 700{ }^{\circ} \mathrm{C}$ for the $\mathrm{HP}$ event recorded in mafic rocks and at $0.7 \mathrm{GPa} / 720{ }^{\circ} \mathrm{C}$ for the regional amphibolite-facies overprint (Liati and Seidel, 1996; Moulas et al., 2013). Metapelite assemblages record higher pressure for the high-temperature overprint (1.2-1.3 GPa / 700-730 ${ }^{\circ} \mathrm{C}$; Krenn et al., 2010). To the northeast, Maastrichtian - Ypresian deposits (Boyanov et al., 1982; Goranov and Atanasov, 1992) rest with fault contacts on basement gneisses (Bonev et al., 2006) and party overlap, in age, with Latest Cretaceous-Earliest Oligocene plutonic rocks and volcanics (e.g., Peytcheva et al., 1998; Soldatos et al., 2001; 2008; Ovtcharova et al., 2003; Marchev et al., 2006, 2010; Jahn-Awe et al., 2010; Filipov and Marchev, 2011).

The Southern Rhodope Core Complex (SRCC) is a wide metamorphic dome of roughly triangular shape that shows a flat-lying foliation over its width and lies immediately southwest of the NRD (Brun and Sokoutis, 2007) (Fig.2). The contact between the SRCC and the NRD is located along a mylonite-bearing syn-metamorphic SW-verging thrust fault known as the Nestos Thrust (e.g., Papanikolaou and Panagopoulos, 1981; Gerdjikov and Milev, 2005). The SRCC consists of highly deformed Permian-Carboniferous mylonitic orthogneisses, micaschists and 
amphibolites capped by a thick marble sequence (e.g., Kronberg et al., 1970; Turpaud and Reischmann, 2010). The gneisses reached upper greenschist/lower amphibolite-facies conditions and the available metamorphic ages are post-Early Eocene (i.e., post-51 Ma) (Wawrzenitz and Krohe, 1998; Lips et al., 2000). Oligo-Miocene plutonic bodies that show syn-tectonic fabrics intruded the basement rocks (Kolocotroni and Dixon, 1991; Kaufman, 1995; Dinter et al., 1995; Eleftheriadis et al., 2001). Widespread NW-SE-trending basins were developed after Middle Miocene (e.g., Snel et al., 2006).

Gravity spreading of the thickened Hellenic crust during the Early Cenozoic extension led to the exhumation of the SRCC that separated the NRD, to the northeast, from the Chalkidiki block to the southwest (Fig.2; see also fig.4 in Kydonakis et al., 2015a). Exhumation was controlled by the Kerdylion Detachment whose hanging-wall is the Chalkidiki block (Brun and Sokoutis, 2007). In the course of exhumation, the Chalkidiki block (i) behaved as a coherent block that rotated $30^{\circ}$ clockwise during the Paleogene and was only affected by moderate internal deformation, (ii) underwent moderate brittle north-south extension since the Middle Miocene and (iii) was only locally intruded by magmatic bodies during the Tertiary (Kondopoulou and Westphal, 1986; Brun and Sokoutis, 2004; 2007). The tectono-thermal history of the Chalkidiki block created rather favourable conditions for maintaining isotopic evidence of the cooling path after peak metamorphic conditions.

\subsection{The south-western part of the Rhodope: the Chalkidiki block}

A number of south-westward verging thrusts separated by sharp NW-trending contacts define the Chalkidiki block. For the purpose of this study we will investigate the two easternmost 
units that are the Vertiskos Unit, to the east, and the Circum-Rhodope belt, to the west (Kockel et al., 1971; 1977; Kauffmann et al., 1976; Kockel and Mollat, 1977) (Fig.3).

The Vertiskos Unit is an elongated NW-trending basement belt with complex tectonometamorphic history (Fig.3). It is made of Silurian - Ordovician granitoids (later transformed into orthogneisses), paragneisses, thin marble horizons, leucocratic granitic/pegmatitic intrusions, deformed amphibolites, scarce eclogite boudins and serpentinites (Kockel et al., 1971, 1977; Himmerkus et al., 2009a). The Arnea-Kerkini Magmatic Complex intruded the Vertiskos Unit during the Early Triassic (Himmerkus et al., 2009b) and both, as a coherent basement complex, experienced the same post-intrusion metamorphic overprint(s) (Burg et al., 1995; Kilias et al., 1999). Metamorphic K-Ar ages range between 140 and 90 Ma (e.g., Borsi et al., 1965; Harre et al., 1968; Marakis, 1969; Papadopoulos and Kilias, 1985; Christofides et al., 1999) (Fig.4). Rubidium/strontium metamorphic ages show intense dispersion and a number of non-reset Permian - Jurassic ages but the youngest age cluster correlates well with the Cretaceous K-Ar metamorphic ages (e.g., Zervas et al., 1979; Papadopoulos and Kilias, 1985; de Wet et al., 1989) (Fig.4). Lips et al. (2000) reported a $143 \pm 5 \mathrm{Ma}{ }^{40} \mathrm{Ar} /{ }^{39} \mathrm{Ar}$ age (white mica; plateau age) from a quartz-calcite mylonite and de Wet et al. (1989) a $136 \pm 1$ Ma (biotite; plateau age) from the Arnea Magmatic Complex (Fig.4).

The Circum-Rhodope belt is a Triassic - Jurassic meta-sedimentary sequence locally involving Triassic rhyolites and quartzites at the base (Kauffmann et al., 1976; Asvesta and Dimitriadis, 2010; Meinhold and Kostopoulos, 2013) (Fig.3). It is largely made of phyllites, schists and carbonates and is considered as the Mesozoic sedimentary cover of the Vertiskos Unit (Kockel et al., 1971; Kauffmann et al., 1976; Dixon and Dimitriadis, 1984). Outliers of the Mesozoic Circum-Rhodope belt lie directly on top of the Vertiskos Unit toward the east (Fig.3). 
Part of these outliers were indeed originally mapped as part of the Circum-Rhodope belt (Kockel et al., 1977; see also Dixon and Dimitriadis, 1984) but re-interpreted later as individual units under various local names such as the "Nea Madytos Unit" of Sakellariou and Dürr (1993) or the "Bunte Serie" of Papadopoulos and Kilias (1985). This basement-cover complex lies beneath a thin basement fragment through a sharp NW-trending thrust contact (Kydonakis et al., 2015b) (Fig.3). For convenience, the terms "upper basement slice" and "lower basement-cover complex" will be used hereafter for the hanging-wall and foot-wall of the thrust contact, respectively. Basal rhyolites of the Circum-Rhodope belt yield Early Cretaceous ( 120 Ma) K-Ar metamorphic ages (Bertrand et al., 1994) (Fig.4).

Evidence of a HP event from the Chalkidiki block is found in Asvesta (1992) who reported high-Si phengite from the base of the Circum-Rhodope belt and Michard et al. (1994) who reported the existence of high-Si phengite (3.52 atoms per formula unit - apfu) from basal rhyolitic meta-tuffs. Michard et al. (1994) estimated peak metamorphic conditions at circa 0.8 $\mathrm{GPa} / 350{ }^{\circ} \mathrm{C}$ for the HP event to the west. Thermodynamic bulk-rock considerations allowed more precise P-T estimations: (i) to the east, peak eclogite-facies conditions at $1.9 \mathrm{GPa} / 520{ }^{\circ} \mathrm{C}$ and amphibolite-facies re-equilibration at $1.2 \mathrm{GPa} / 620^{\circ} \mathrm{C}$ and (ii) to the west, a pressure of up to 1.4-1.5 GPa may have been reached during the HP event (Kydonakis et al., 2015c).

\section{Analytical methods}

\section{$3.1{ }^{40} \mathrm{Ar} /{ }^{39}$ Ar step heating method}


Fresh samples of phyllites, gneisses and mica-schists were selected for step-heating laser probe ${ }^{40} \mathrm{Ar} /{ }^{39} \mathrm{Ar}$ dating. The samples were crushed, sieved prior to handpicking (single mica grains) under binocular microscope and cleaning in ultrasonic bath using acetone and distilled water. Biotites and white micas were packaged in aluminium foils and irradiated in the core of the Triga Mark II nuclear reactor of Pavia (Italia) with several aliquots of the Fish Canyon sanidine standard (28.03 $\pm 0.08 \mathrm{Ma}$ ) (Jourdan and Renne, 2007) as flux monitor. Argon isotopic interferences on $\mathrm{K}$ and $\mathrm{Ca}$ were determined by irradiation of $\mathrm{KF}$ and $\mathrm{CaF}_{2}$ pure salts from which the following correction factors were obtained: $\left({ }^{40} \mathrm{Ar} /{ }^{39} \mathrm{Ar}\right)_{\mathrm{K}}=0.00969 \pm 0.00038,\left({ }^{38} \mathrm{Ar} /{ }^{39} \mathrm{Ar}\right)_{\mathrm{K}}=$ $0.01297 \pm 0.00045,\left({ }^{39} \mathrm{Ar} /{ }^{37} \mathrm{Ar}\right)_{\mathrm{Ca}}=0.0007474 \pm 0.000021$ and $\left({ }^{36} \mathrm{Ar} /{ }^{37} \mathrm{Ar}\right)_{\mathrm{Ca}}=0.000288 \pm$ 0.000016. Argon analyses were performed at Géosciences Montpellier (France) with an analytical system that consists of: (a) an IR- $\mathrm{CO}_{2}$ laser of $100 \mathrm{kHz}$ used at 5-15\% during $60 \mathrm{sec}$, (b) a system of lenses for beam focusing, (c) a steel chamber, maintained at $10^{-8}-10^{-9}$ bar, with a drilled copper plate and the four samples on, (d) an inlet line for purification of gases including two Zr-Al getters, (e) a multi-collector mass spectrometer (Argus VI from Thermo-Fisher). A custom-made software controls the laser intensity, the timing of extraction/purification and the data acquisition. To measure the argon background within the system, one blank analysis was performed every three sample analyses. The ArArCalc software $\odot$ v2.5.2 was used for data reduction and plotting. One-sigma errors reported for plateau, isochron and total gas ages include the error on the irradiation factor J. Atmospheric ${ }^{40} \mathrm{Ar}$ was estimated using a value of the initial ${ }^{40} \mathrm{Ar} /{ }^{36} \mathrm{Ar}$ of 295.5 .

\subsection{LA-ICP-MS U-Th-Pb monazite and U-Pb zircon dating}


Monazite grains were imaged in-context on well-polished thin sections by back-scattering imaging using a JEOL JSM-7100F field-emission scanning electron microscope operating at an accelerating voltage of $20 \mathrm{kV}$ available at Université de Rennes 1, France. For zircon grains, a classic separation procedure was followed at the facilities available at Géosciences Rennes, France. The samples were crushed and the zircon grains were separated using a Wilfley table, heavy liquids and a Frantz isodynamic separator before being handpicked under a binocular microscope and embedded in one-inch thick epoxy pucks. Zircon grains were imaged by cathodoluminescence (CL) using a Reliotron CL facility at Géosciences Rennes. LA-ICP-MS isotopic measurements were conducted for both monazite and zircon grains using an ESI NWR193UC Excimer Laser coupled to a quadripole Agilent 7700x ICP-MS at Géosciences Rennes, France. For a complete account of the analytical procedures see Ballouard et al. (2015). Ablation spot diameters of $7 \mu \mathrm{m}$ for monazite or $26 \mu \mathrm{m}$ for zircon with repetition rate of $3 \mathrm{~Hz}$ and laser intensity of $7.5 \mathrm{~J} / \mathrm{cm}^{2}$ were used throughout. The data were corrected for U-Pb and Th$\mathrm{Pb}$ fractionation and for mass bias by standard bracketing with repeated measurements of international standards. For monazite dating, the Moacyr monazite standard (Gasquet et al., 2010) was used. At regular intervals, the Manangoutry monazite $(555 \pm 2 \mathrm{Ma}$; Paquette and Tiepolo, 2007) was used as unknown to ensure quality control of the isotopic measurements $(556.2 \pm 2.6 \mathrm{Ma} ; \mathrm{MSWD}=0.44 ; \mathrm{N}=12)$. For zircon dating, the GJ-1 zircon standard (Jackson et al., 2004) was used whereas the 91500 zircon standard (1065.4 $\pm 0.6 \mathrm{Ma}$; Wiedenbeck et al., $1995)$ was treated as unknown to ensure quality control $(1062 \pm 3 \mathrm{Ma}$; MSWD $=0.098 ; \mathrm{N}=12)$. Data reduction was carried out using the GLITTER $®$ software package developed by Macquarie Research Ltd. (Jackson et al., 2004). Concordia ages and diagrams were generated using Isoplot/Ex (Ludwig, 2001) updated to ver. 2.45/4.15. 


\subsection{Electron microprobe analyses}

Mineral analyses were obtained at ETH Zurich, Switzerland and National Technical University of Athens, Greece using a JEOL JXA-8200 and a JEOL JSM-6380 low vacuum scanning electron microscope both operating at an accelerating voltage of $15 \mathrm{kV}, 2 \mu \mathrm{m}$ beam diameter and $20 \mathrm{nA}$ beam current.

\section{Strategy and samples description}

Nine samples were selected for ${ }^{40} \mathrm{Ar} /{ }^{39} \mathrm{Ar}$ step heating, U-Th- $\mathrm{Pb}$ and U-Pb dating on micas, monazite and zircon, respectively (Table 1). The sampling locations are shown in Fig.3. Five samples belong to the lower basement-cover complex: two samples are from the western part (CR4 and CR10) and another three from the east (SM15, SM40, SM56). With the exception of SM15 for which a protolith age cannot be inferred based on stratigraphic criteria, the remaining samples belong to the Mesozoic sedimentary sequences of the area. Four additional samples belong to the upper basement slice: two samples are from paragneisses of unknown protolith age embedded in the basement (SM24 and SM42) and another two from the Triassic Arnea Magmatic Complex (SM9 and SM78). An overview of the micas and monazite chemistry is given in Fig.5 and Fig.6, respectively. Representative micas and monazite analyses can be found in Table 2 and Table 3, respectively.

\subsection{Phyllites/schists from the lower basement-cover complex}


Sample CR4 is a fine-grained quartz-mica phyllite. In the field it has a dominant foliation and a prominent NW-trending crenulation lineation. The main mineral phases are, in decreasing modal amount, quartz, white mica, chlorite, garnet and opaque minerals. A typical crenulation cleavage is developed by differentiation at the limps of microlithon domains. The microlithons are dominated by quartz and kinked, often chloritised, medium-grained white micas. The cleavage domains are made of fine-grained K-rich white micas or a fine-grained aggregate composed of K-rich white mica, paragonite and chlorite. The Si content of the K-rich mica from the matrix ranges from 3.1 to 3.25 anion per formula unit (apfu) and contains up to 2.4 wt.\% $\mathrm{Na}_{2} \mathrm{O}$. Paragonite from the matrix has a $\mathrm{Na} /(\mathrm{Na}+\mathrm{K})$ ratio around 0.9 apfu and contains small amounts of $\mathrm{Ca}$ (less than $0.1 \mathrm{apfu}$ ). No systematic chemical variation between the large (microlithon domains) and the smaller (crenulation domains) mica grains was observed. Garnet (typically 2-3 $\mathrm{mm}$ in diameter) appears heavily replaced by chlorite and is only preserved as small patches within the chlorite mass. Garnet composition varies between $\mathrm{Alm}_{67} \mathrm{Grs}_{23} \mathrm{Sps}_{6} \mathrm{Pyr}_{4}$ and $\mathrm{Alm}_{60} \mathrm{Grs}_{25} \mathrm{Sps}_{12} \mathrm{Pyr}_{3}$. Despite the chlorite alteration, syn-tectonic feature are still preserved. Quartz in the microlithon domains has healing features and is recrystallised with sharp grain boundaries and virtually no undulose extinction. Representative back-scattered images are given in Kydonakis et al. (2015c; fig.2).

Sample CR10 is a fine-grained phyllite with a dominant NW-trending crenulation lineation. Main phases are quartz, phengitic white mica and subordinate chlorite. The bedding can potentially be recognised as the interface between quartz- and white mica-rich layers. An anastomosing network of crenulation cleavage is defined by fine-grained white micas. Chlorite occasionally replaces the white mica. Phengite contains up to 3.31 apfu $\mathrm{Si}$ and also small amounts of $\mathrm{Na}$ (typically less than 0.4 wt.\%). 
Sample SM15 is a medium-grained garnet-kyanite micaschist. It appears in a relatively small isolated outcrop to the east and is intercalated with orthogneisses and highly-deformed amphibolites. It contains quartz, garnet, kyanite, white mica and rutile as the main phases and staurolite, chlorite, biotite (only as inclusion), ilmenite, epidote, phosphates, zircon and opaques as accessory phases. In the field it displays shear bands and rounded garnet/kyanite porphyroclasts surrounded by medium-grained matrix made of K-rich white mica. The K-rich white mica has Si content up to $3.36 \mathrm{apfu}$, contains up to $1.92 \mathrm{wt} . \% \mathrm{Na}(\sim 0.24 \mathrm{apfu})$ and is sometimes chloritised especially near the garnet rim. Garnet appears mostly anhedral, range from $500 \mu \mathrm{m}$ to $3 \mathrm{~mm}$ in diameter and shows a weak zoning in major elements with almost flat spessartine/grossular components, increasing almandine and decreasing pyrope components toward the rim. Its composition ranges from $\mathrm{Alm}_{64} \mathrm{Grs}_{5} \mathrm{Sps}_{5} \mathrm{Pyr}_{26}$ to $\mathrm{Alm}_{73} \mathrm{Grs}_{5} \mathrm{Sps}_{5} \mathrm{Pyr}_{17}$ from core to rim. Monazite appears mostly in the matrix, often surrounded by a reaction corona, in relation with apatite; monazite inclusion in garnet also exists.

Sample SM40 is a garnet-staurolite micaschist from the eastern part of the area. Major phases are white mica, quartz, garnet, chlorite, staurolite and sub-ordinate kyanite. Accessory minerals are monazite, zircon and rarely ilmenite and allanite. The matrix is made of phengite, paragonite, rutile and quartz. Potassium-rich white mica is dominant in the matrix and contains up to 3.25 apfu Si and up to 0.24 apfu Na. Paragonite is less abundant with $\mathrm{Na} /(\mathrm{Na}+\mathrm{K})$ ratio up to 0.9 and contains less than $1 \mathrm{wt} . \% \mathrm{Ca}(<0.04 \mathrm{apfu})$. Garnet appears as euhedral to subhedral grains measuring up to $1.5 \mathrm{~cm}$ in diameter and contains white mica, rutile, ilmenite, chlorite, rare pyrite and an impressive amount of tourmaline as aligned inclusions. It displays zoning in major elements with $\mathrm{Alm}_{65} \mathrm{Grs}_{20} \mathrm{Sps}_{11} \mathrm{Pyr}_{4}$ cores and $\mathrm{Alm}_{80} \mathrm{Grs}_{9} \mathrm{Sps}_{0} \mathrm{Pyr}_{11}$ rims. Shear bands and 
macroscopically visible spiral garnet indicate a top-to-the SW shear in hand specimen. Both garnet and staurolite preserve syn-tectonic features.

Sample SM56, although similar to SM40, it is more quartz-rich and its matrix is more fine-grained as a result of deformation. In thin section, garnet porphyroclasts measure up to 0.3 $\mathrm{cm}$ in diameter and show consumption textures. Staurolite can barely be recognised in thin sections and is often replaced by shimmer. This sample has suffered grain size reduction compared to SM40 possibly during retrogression.

\subsection{Paragneisses and orthogneisses from the upper basement slice}

\subsubsection{Paragneisses of unknown protolith age embedded in the basement}

Sample SM42 is a medium-grained garnet-bearing micaschist cropping out at the centralnorth part of the study area. It has a pronounced foliation and SW-directed shear indicators. It contains small garnet porphyroblasts (typically less than $2 \mathrm{~mm}$ ) surrounded by matrix made of $\mathrm{K}$ rich white mica, biotite, quartz, ilmenite and subordinate plagioclase. Chlorite, phosphates, zircon and rutile appear as accessory minerals. The foliation is made by biotite and white micas. Biotite, although commonly found along the foliation plane, appears with anhedral grains which look like re-oriented porphyroclasts rather than growing in equilibrium with the white micas from the foliation. According to their textural position and size, two types of white micas are found: (i) big mica flakes, commonly at high angle to the foliation, and (ii) medium- to finegrained micas found along the foliation plane. The latter white micas have Si content of up to 
3.29 (apfu) and contain less than $1.3 \mathrm{wt} . \% \mathrm{Na}$. Garnet is up to $2 \mathrm{~mm}$ in diameter and shows a pronounced prograde zoning in major elements with decreasing spessartine/grossular and increasing almandine/pyrope components. Its composition range from $\mathrm{Alm}_{57} \mathrm{Grs}_{28} \mathrm{Sps}_{12} \mathrm{Pyr}_{3}$ to $\mathrm{Alm}_{79} \mathrm{Grs}_{10} \mathrm{Sps}_{1} \mathrm{Pyr}_{10}$ from core to rim.

Sample SM24 is a medium-grained garnet-kyanite micaschist also from the central-north part of the study area. It displays eye-shaped aggregates of garnet, biotite and kyanite surrounded by fine-grained matrix made mostly of K-rich white micas and quartz. Accessory minerals are ilmenite, zircon, phosphates and opaques. White micas from the matrix have a phengitic composition (up to $3.26 \mathrm{apfu}$ ). Garnet is typically around $2 \mathrm{~mm}$ in diameter (few bigger grains with $5 \mathrm{~mm}$ diameter were also found). Garnet shows a rather flat major element composition with almandine/pyrope dominating over the spessartine/grossular components and typical composition of $\mathrm{Alm}_{75} \mathrm{Grs}_{15} \mathrm{Sps}_{7} \mathrm{Pyr}_{3}$. Monazite appears in the matrix or as inclusion in the garnet and displays patchy zoning.

\subsubsection{Orthogneisses of the Triassic Arnea Magmatic Complex}

Samples SM9 and SM78 are both leucocratic orthogneisses from the Triassic Arnea Magmatic Complex. They contain K-feldspar, quartz, K-rich white mica, plagioclase and subordinate biotite as major mineral phases and zircon, rutile, apatite as accessory minerals. Despite the metamorphic overprint, both samples have preserved magmatic textures (such as myrmekites). Potassium-rich white micas are metamorphic in origin. For both samples, K-rich white mica from the foliation have up to 3.27 apfu Si content and contain negligible amount of Na. 


\section{Results}

\section{$5.1{ }^{40} \mathrm{Ar} /{ }^{39} \mathrm{Ar}$ step heating results}

Eight samples were used for ${ }^{40} \mathrm{Ar} /{ }^{39} \mathrm{Ar}$ micas dating. Degassing data and age spectra plots are shown in Appendix A.1 and Fig.7, respectively. A synopsis of the ${ }^{40} \mathrm{Ar} /{ }^{39} \mathrm{Ar}$ ages is given in Table 4. For the white mica we adopt a closure temperature of $420 \pm 30^{\circ} \mathrm{C}$ according to Harrison et al. (2009). This has to be considered as a minimum value since the closure temperature increases with the $\mathrm{Mg} / \mathrm{Fe}$ ratio in phengite as well as with the grain size and the cooling rate (Agard et al., 2002; Augier et al., 2005). According to Harrison et al. (1985), the closure temperature of the biotite is $320^{\circ} \mathrm{C} \pm 30^{\circ} \mathrm{C}$.

\subsection{1 (Mesozoic) phyllites/schists from the lower basement-cover complex}

For sample CR4, two age spectra were obtained. Two slightly different plateau apparent ages of $124.1 \pm 0.7 \mathrm{Ma}\left(100 \%\right.$ of ${ }^{39} \mathrm{Ar}$ released $)$ and $119.2 \pm 0.8 \mathrm{Ma}\left(80 \%\right.$ of ${ }^{39} \mathrm{Ar}$ released $)$ were calculated for a single and three smaller grains, respectively (Fig.7a). The obtained dates overlap with the corresponding inverse isochron dates $(123.5 \pm 1.4 \mathrm{Ma}$ and $118.9 \pm 1.0 \mathrm{Ma}$, respectively). As discussed in the description of the sample, bigger mica grains are commonly found in the microlithons whereas smaller grains are typical for the cleavage domains. Although the small grains possibly crystallised after the larger ones (based on the rock's texture) we cannot quantify the difference in time but cannot significantly exceed 5 m.y. (equal to the difference in 
the plateau ages). The difference in the plateau ages can alternatively attributed to a diffusioncontrolled process that originates within the variation in the grain size. Thus, the date of ca. 125 Ma is interpreted as the cooling age of the rock.

For sample CR10, two sets of relatively small white micas were analysed. Both apparent age spectra show evidence for partial argon loss and the individual steps for both of them are roughly constrained between ca. 128 and 112 Ma. For the six-grain dataset (black line - Fig.7b), the third step produced the oldest date, $126.8 \pm 0.9 \mathrm{Ma}$, which can be considered as the minimum age of an older component and it is very close to plateau apparent age obtained for sample CR4 (i.e. $124.1 \pm 0.7 \mathrm{Ma}$ ) from the same unit. Six out of the 11 steps yield a weighted date of ca. 115 $\mathrm{Ma}\left(67 \%\right.$ of ${ }^{39} \mathrm{Ar}$ released) which is similar to the small grains of CR4 (119.2 $\left.\pm 0.8 \mathrm{Ma}\right)$. Despite a large MSWD value linked to the high radiogenic content of the sample, these dates overlap with the inverse isochron date of $118.3 \pm 3.4 \mathrm{Ma}$. For the eight-grain dataset (light grey line Fig.7b) the central part of the spectra (62\% of ${ }^{39}$ Ar released) yielded a weighted mean date of ca. $125 \mathrm{Ma}$ and a meaningless inverse isochron date of $119.0 \pm 8.1 \mathrm{Ma}$. The shape of the two apparent age spectra suggests that several reservoirs contribute to the released argon; yet the convex pattern first described by Wijbrans and McDougall (1986) was not observed. This could indicate that, in addition to the two white mica end-members, argon was released from a third component such as an interlayered chlorite that partly replaced muscovite. Overall, the age of the sample can be constrained between ca. 112 and $128 \mathrm{Ma}$. This is supported by the total fusion age of $126.6 \pm 0.5 \mathrm{Ma}$ for a single-grain white mica (dark grey line - Fig.7b) that is very close to the assumed older end-member. In summary, the most representative age for this sample, ignoring all the complexity involving multi-grain analysis, should be around $125 \mathrm{Ma}$. 
For sample SM15 three single white mica grains were analysed (Fig.7c). The smallest one yielded a convex age spectrum (black line) which is reminiscent of the spectra described by Wijbrans and McDougall (1986) for mixture of mica populations. However, the other two gave reasonably flat degassing patterns with $95.4 \pm 0.8 \mathrm{Ma}$ (plateau age; $64 \%$ of ${ }^{39} \mathrm{Ar}$ released; medium grey line) and $95.9 \pm 0.4 \mathrm{Ma}$ (total fusion age; dark grey line) (Fig.7c). The dates obtained overlap with the calculated inverse isochron dates. These dates are indistinguishable within error with those obtained from samples SM40 (ca. 98 Ma) and SM56 (92.2 $\pm 1.9 \mathrm{Ma}$ ) (see below) from the same Mesozoic schists from the eastern part of the study area.

For sample SM40, three relatively large white mica grains were individually dated. All of them produced flat to weakly concave age spectra with total fusion ages in the range $97-100$ Ma, similar to the corresponding inverse isochron dates (Fig.7d). Note the large MSWD values and the error bars due to the clustering of the data points near the abscissa. The reproducibility of the results for the three grains suggests an age of $98 \pm 2 \mathrm{Ma}$ as the most representative cooling age for this sample.

Five smaller white mica grains separated from sample SM56 display a complex, partially saddle-shaped spectrum that is usually interpreted as due to excess argon contamination (Fig.7e inset). In the ${ }^{36} \mathrm{Ar} /{ }^{40} \mathrm{Ar}$ vs. ${ }^{39} \mathrm{Ar} /{ }^{40} \mathrm{Ar}$ plot, the data points form a linear array corresponding to an intercept date of $93.1 \pm 4.0 \mathrm{Ma}$, with an initial ${ }^{40} \mathrm{Ar} /{ }^{36} \mathrm{Ar}$ value of $1843 \pm 74$. Correcting the primary age spectrum with this initial argon ratio, a plateau age of $92.2 \pm 1.9$ Ma can be calculated for $70 \%$ of released ${ }^{39} \mathrm{Ar}$ (Fig.7e). This age is only $\sim 4-8 \mathrm{~m}$.y. younger than that of the SM40 probably as a result of a smaller grain size or different chemical properties. 


\subsubsection{Paragneisses and orthogneisses from the upper basement slice}

\subsubsection{Paragneiss of unknown protolith age embedded in basement orthogneisses}

Both biotite and white mica were separated from sample SM42 (Fig.7f). The single grain biotite age spectrum shows typical argon pattern with young dates in the first heating increments at about $30 \mathrm{Ma}$ that progressively increase to a relatively tight group of dates between ca. 140 and $150 \mathrm{Ma}$ (mean date of $145.7 \pm 2.1 \mathrm{Ma} ; 57 \%$ of ${ }^{39} \mathrm{Ar}$ released). However, no reasonable plateau age can be calculated. The calculated inverse isochron date is $141.4 \pm 2.3 \mathrm{Ma}$. This is identical within error with the $146.9 \pm 3.0$ Ma total fusion age calculated by Lips et al. (2000) from white micas of a mylonite of the Vertiskos Unit further southeast. From the same sample, three single white mica grains of same size were analysed. One of them yield a saddle-shaped spectrum indicative for excess argon (light grey line - Fig.7f). However, no linear array was observed in the inverse isochron plot and no correction could be applied to the age spectrum. The other two spectra (dark grey and medium grey lines - Fig.7f) yield more concordant age patterns with total fusion dates of $138.6 \pm 0.6 \mathrm{Ma}$ and $126.5 \pm 0.5 \mathrm{Ma}$, respectively (inverse isochron dates of $137.5 \pm 1.1$ and $127.8 \pm 2.2 \mathrm{Ma}$ ). Complexity on calculating a single age for this particular sample comes from the fact that the three white micas have recorded different apparent ages. This can be the result of variable excess argon incorporation or due to complex chemical variations. However, based on the youngest reasonable date (possibly the least affected by excess argon) it seems that the sample cooled below the blocking temperature at maximum at ca. 126 Ma. This sample is more likely part of the intercalated Palaeozoic sequences within the basement and the older age spectra obtained are more probably the result of partial reset of the system 
during an event around (at maximum) $126 \mathrm{Ma}$. This conclusion is supported by the fact that the circa $125 \mathrm{Ma}$ event is already well constrained from the samples CR4 and CR10 (described above) and from the samples SM78 and SM9 that will be described below.

\subsubsection{Triassic Arnea Magmatic Complex}

One white mica and one biotite grain were dated from sample SM78 (Fig.7g). The white mica yield a well-defined plateau age of $123.1 \pm 0.5 \mathrm{Ma}\left(97 \%\right.$ of ${ }^{39} \mathrm{Ar}$ released) (black line) and an identical inverse isochron date of $123.0 \pm 0.7 \mathrm{Ma}$ with atmospheric initial argon. This age is very similar to those obtained from CR4 and CR10 few kilometres to the south. From the same sample, the biotite produced a convex age spectrum with maximum dates scattering between 55 and $60 \mathrm{Ma}$ (grey line) (Fig.7g). A plateau age was calculated at $59.7 \pm 0.7 \mathrm{Ma}\left(36 \%\right.$ of ${ }^{39} \mathrm{Ar}$ released) but no reliable inverse isochron age could be calculated. The age difference between the two minerals from the same sample cannot be interpreted in terms of their closure temperature differences as this would involve a period of about $60 \mathrm{~m} . \mathrm{y}$. . Due to its higher sensitivity to thermal overprint, it is likely that the biotite shows evidence for, almost complete, reset during late processes. This scenario is indeed compatible with the intrusion in the area of voluminous plutons during the Early Eocene (e.g., de Wet et al., 1989; Frei, 1996).

Two white micas were dated from sample SM9 both producing identical plateau ages $\left(124.3 \pm 0.5 \mathrm{Ma}\right.$ for $86 \%{ }^{39} \mathrm{Ar}$ released and $124.6 \pm 0.5 \mathrm{Ma}$ for $98 \%$ of ${ }^{39}$ Ar released) which are also similar to the calculated inverse isochron dates (Fig.7h) and to that of the white mica of sample SM78 from the same unit. 


\subsection{LA-ICP-MS U-Th-Pb monazite and U-Pb zircon dating}

Two samples from the eastern and northern parts of the study area were selected for LAICP-MS in situ U-Th-Pb monazite dating in-context in thin sections and $\mathrm{U}-\mathrm{Pb}$ zircon dating on separated minerals: one sample (SM24) comes from the upper basement slice and one sample (SM15) from the lower basement-cover complex (Fig.3).

Monazite grains from both samples display similar compositional variation and belong to the monazite-Ce species. Their $\mathrm{P}_{2} \mathrm{O}_{5}$ content varies between 27.32 and 31.49 wt. $\%$ and the $\mathrm{UO}_{2}$ content is for most of the grains low $(<0.1$ wt.\%). The REE, Th, Y and Ca contents vary: for $\mathrm{Ce}_{2} \mathrm{O}_{3}$ from 27.81 to 34.81 wt. $\%$, for $\mathrm{La}_{2} \mathrm{O}_{3}$ from 10.53 to 14.30 wt.\%, for $\operatorname{Pr}_{2} \mathrm{O}_{3}$ from 1.75 to 4.74 wt. $\%$, for $\mathrm{Nd}_{2} \mathrm{O}_{3}$ from 8.36 to 14.86 wt. $\%$, for $\mathrm{ThO}_{2}$ from 0.6 to 16.77 wt. $\%$, for $\mathrm{Y}_{2} \mathrm{O}_{3}$ from zero to 4.98 wt.\% and for $\mathrm{CaO}$ from 0.35 to 2.44 wt.\%. The isotopic datasets are given in Appendix A.2 for monazite and Appendix A.3 for zircon.

\subsubsection{Schist from the lower basement-cover complex}

Sample SM15 contains homogenous monazite grains with no obvious zoning in major elements (Fig.8a). Huttonite substitution varies up to $9 \%$ whereas brabantite substitution ranges between 3 and 10\%. No evidence for common $\mathrm{Pb}$ is found in Fig.9a. Monazite grains found in the matrix and as inclusions (in garnet, kyanite and white micas) were dated. The obtained concordant dates range from 310 to $128 \mathrm{Ma}$. This age scatter reflects differences between individual grains and/or heterogeneities within single grains. Monazites from this sample are commonly decomposed at their outer parts into a corona made of apatite(ap)-allanite(all)epidote(ep) according to the reaction (Fig.8a): 


$$
\text { Mon }=\text { Ap + REE-rich All + REE-Ep }
$$

Similar REE-mobilisation reactions have been described in amphibolite-facies metamorphic rocks elsewhere (e.g., Broska and Siman, 1998; Finger et al., 1998). Such textures depend on the composition of the metamorphic fluids ( $\mathrm{Ca}$ bulk content and $\mathrm{Ca} / \mathrm{Na}$ ratio) in addition to the P-T conditions (Majka and Budzyn 2006; Budzyn et al., 2011; Krenn et al., 2012; and references therein). We note here that only the monazites grains found in the matrix are surrounded by these coronas whereas the monazite grains protected from fluid interactions (as inclusions in garnet and kyanite) do not show any reaction textures. Quite commonly, different dates were obtained for the cores and rims of the decomposed grains. At the rims, the dominant date cluster is Early Cretaceous with a calculated concordia date at $132.5 \pm 0.3 \mathrm{Ma}$ (Fig.9a). Concordant core dates (or dates from non-decomposed monazites) are found between $\sim 310$ and 230 Ma with a dominant Late Permian cluster (concordia date of $257.4 \pm 1.1$ Ma; Fig.8a) (Figs.8a,9a). Brabandite or huttonite substitutions show no correlation with the calculated dates.

Concordant zircon $\mathrm{U}-\mathrm{Pb}$ ages scatter from 2357 to $122.7 \pm 2.1 \mathrm{Ma}\left({ }^{206} \mathrm{~Pb}-{ }^{238} \mathrm{U}\right.$ ages); the youngest concordant date is $216.7 \pm 3.2\left({ }^{206} \mathrm{~Pb}^{-238} \mathrm{U}\right.$ age) (Fig.9b). More than half of the zircon grains dated lie in the range 216 to $\sim 300 \mathrm{Ma}$ and the majority of them at $248.2 \pm 1.3 \mathrm{Ma}$ (concordia age; Fig.9b).

\subsubsection{Paragneiss from the upper basement slice}

Sample SM24 revealed patchy monazite zoning in back-scattered images (Fig.8b). For this sample, monazite grains found both in the matrix and as inclusion in garnet and micas were dated. Huttonite substitution varies up to $2.5 \%$ whereas brabantite substitution ranges between 3 
and $11 \%$. As seen in Fig.9c there is no evidence for the presence of common $\mathrm{Pb}$ in these monazite grains; the age scatter corresponds to differences between individual grains and/or to heterogeneities within single grains. The obtained concordant dates range from $362.2 \pm 3.7 \mathrm{Ma}$ down to $208.6 \pm 2.3\left({ }^{232} \mathrm{Th}-{ }^{208} \mathrm{~Pb}\right.$ ages $)$. The majority of the concordant dates cluster around 300 - $280 \mathrm{Ma}$; a concordia date at $302 \pm 0.8 \mathrm{Ma}$ was calculated for some of these grains (Fig.9c). Brabandite substitution shows a positive correlation with the obtained dates.

Age scatter is also evidenced by the zircon analyses (Fig.9d). The majority of dates are concordant or slightly discordant. The obtained dates range from 670 to $570 \mathrm{Ma}$ and from 400 to $300 \mathrm{Ma}$; the youngest concordant date is $307.2 \pm 3.8$ (Ma) (Fig.9d).

\subsection{Interpretation of the results}

A wild variety of dates are revealed by LA-ICP-MS analyses on monazites and zircons from a schist and a paragneiss (Fig.9). Based on stratigraphic criteria, no deposition age can be assigned to these two samples. However, a great number of various pre-220 Ma dates can be assigned to the crystallisation ages of what we interpret as detrital monazite and zircon grains. In particular, the most visible age clusters can be found approximately at 230-250, 300-360, 400460 and 500-600 Ma. These ages can be directly related to Early Mesozoic - Palaeozoic magmatic -and metamorphic- events recorded everywhere in the region (e.g., Himmerkus et al., 2006; 2007; 2009a; 2009b; Turpaud and Reischmann, 2010). For sample SM15, the youngest almost concordant detrital zircon age is $\sim 217 \mathrm{Ma}$ and sets a maximum Late Triassic deposition age (Fig.9b). However, there is no known thermal event at that time and, thus, this single age cannot be used to infer the deposition age. Many concordant zircon ages are found at $\sim 230-250$ 
Ma (Fig.9b). Contributing sources are likely linked to the well-known event related to the intrusion of voluminous plutons collectively known, in the study area, as the Arnea-Kerkini Magmatic Complexes. Thus, based on the detrital monazite (Fig.9a) and zircon populations (Fig.9b) we consider that the deposition age of sample SM15 is post-230 Ma. For sample SM24, the youngest concordant zircon age is $\sim 300 \mathrm{Ma}$ (Fig.9d). This weakly constrains the maximum deposition age for this sample as post-Carboniferous. In addition, there are plenty (>20) of 280$300 \mathrm{Ma}$ concordant monazite ages as well as two concordant ages around $210-220 \mathrm{Ma}$ (Fig.9c). Hence, the maximum deposition age of this sample is, in all probability, 210 Ma.

For sample SM15 (lower basement-cover complex) we identified a well-defined Early Cretaceous ( 132 Ma) monazite age cluster that is related to re-crystallisation and isotopic resetting contemporaneous with REE-mobilisation and the formation of apatite-allanite-epidote coronas at the rims of matrix monazite grains (Figs.8a,9a). In the same sample, monazite cores and non-decomposed monazite grains (inclusions in garnet) preserve their initial isotopic compositions and the corresponding calculated ages range from Early Triassic to Carboniferous (Fig.9a). No correlation between brabandite substitution and the corresponding ages is found which ensures preservation of the Th- $\mathrm{Pb}$ ages and no disturbance of the isotopic system during the re-crystallisation process (Poitrasson et al., 1996; Seydoux-Guillaume et al., 2002; Eglinger et al., 2014). As a results, the obtained age clusters are considered geologically meaningful. Similar reaction textures around monazites are commonly described in amphibolite-facies rocks (e.g., Broska and Siman, 1998; Finger et al., 1998). Textural observations dictate that monazite coronas formed after garnet crystallisation as there are no coronas in monazites included in garnet grains. Although the P-T range of garnet formation is not defined for this particular sample, thermodynamic considerations for the whole unit implies that garnet crystallised 
between 500 and $580{ }^{\circ} \mathrm{C}$ on a prograde path from the eclogite-facies to the amphibolite-facies whereas the maximum temperature reached in the thermal history is $\sim 620{ }^{\circ} \mathrm{C}$ (Figs.9,A2 in Kydonakis et al., 2015c). Consequently, assuming similarities in terms of P-T conditions throughout the unit, monazites in our sample (SM15) re-crystallised, in all probability, either near the peak-temperature of the amphibolite-facies $\left(\sim 620^{\circ} \mathrm{C}\right)$ or during the cooling path from the peak-temperature to the low-temperature boundary of the amphibolite-facies. In any case, regarding the uncertainties involved in our approach we consider the $\sim 132 \mathrm{Ma}$ age as a minimum age for monazite breakdown. On the contrary, the sample from the upper basement slice (SM24) lacks similar breakdown coronas or Cretaceous monazite ages which implies that this sample did not experience monazite re-crystallisation preserving the original detrital monazite isotopic compositions (Fig.8c).

Reliable ages were obtained by ${ }^{40} \mathrm{Ar} /{ }^{39} \mathrm{Ar}$ step heating dating on micas. A reference closure temperature of $420 \pm 30{ }^{\circ} \mathrm{C}$ (Harrison et al., 2009) that roughly corresponds to greenschist-facies conditions was adopted for the white mica grains. The adopted closure temperature is lower than the maximum temperature reached during peak metamorphism and thus, the obtained argon ages can be interpreted as cooling ages (see Kydonakis et al., 2015c). Interpreting the age spectra is rather straightforward (Fig.7a-e,g,h) with the exception of the paragneiss embedded in basement orthogneisses (SM42) for which inheritance may cause meaningless dates (Fig.7f). However, even in this case consistent data were extracted from the most likely complete reset grain (medium grey line Fig.7f). Our results clearly document cooling below the closure temperature at 120-125 Ma for the western and northern parts and at 95-100 Ma for the central-eastern part of the study area. Although the age of the peak-pressure metamorphism is unknown, the age of $\sim 132$ Ma calculated for the amphibolite-facies overprint 
to the east (Fig.9a) fits well with the 95-100 Ma cooling ${ }^{40} \mathrm{Ar} /{ }^{39} \mathrm{Ar}$ ages obtained from the same area (Fig.7c-e).

\section{Discussion}

\subsection{The Chalkidiki block: geological structure and the inferred P-T-t path from peak metamorphism to mid-crustal and near surface arrival}

A major syn-metamorphic thrust appears to bring a basement slice (clearly of Vertiskos Unit origin) on top of a basement-cover complex (i.e., Vertiskos Unit plus Circum-Rhodope belt) (Kydonakis et al., 2015b). Using the results of the latter authors, we have superposed our geochronology findings on their NW-trending cross-section (Fig.10). Recently discovered pelitic eclogites to the eastern part of the study area coincide with the deepest exposed part of the lower basement-cover complex (Kydonakis et al., 2015c). At this location, the metamorphic conditions

are estimated at $1.9 \mathrm{GPa} / 520{ }^{\circ} \mathrm{C}$, for the peak event, and at $1.2 \mathrm{GPa} / 620{ }^{\circ} \mathrm{C}$ for the amphibolite-facies overprint (Kydonakis et al., 2015c) (Fig.10). The timing of the eclogite-facies event is unknown. However, we argued here that the Early Cretaceous ( 132 Ma; Fig.9a) breakdown and isotopic re-equilibration of detrital Carboniferous - Early Triassic monazites occurred during the amphibolite-facies conditions and in all probability either at, or shortly after the peak-temperature.

The metamorphic conditions experienced by the equivalent complex further to the west (exposed beneath an upper basement slice) decrease to blueschist/greenschist conditions; clearly 
this part of the complex remained at shallower crustal levels than its eastern counterpart during metamorphism (Michard et al., 1994) (Fig.10). The age of the peak-pressure event there is unclear. However, based on the existence of Tithonian sediments that are involved in the thrust system and that contain neo-formed glaucophane, albite, sericite and epidote (Ricou, 1965), the high-pressure event can be tentatively defined as post-Late Jurassic in age.

Post-peak cooling of the Chalkidiki block is constrained by ${ }^{40} \mathrm{Ar} /{ }^{39} \mathrm{Ar}$ dating on micas. The deepest part of the exposed pile (eastern basement-cover complex) yielded the youngest ages that are between 95 and 100 Ma (Fig.10). Thus, this part reached mid-crustal levels by the early Late Cretaceous. However, the western counterpart of the complex reached the same crustal levels earlier and at around 120-125 Ma (Fig.10). Interestingly, this is exactly the time when the uppermost basement slice reached the same crustal level (Fig.10). This clearly demonstrates that thrusting in the study area must have ceased by the early Late Cretaceous because both sides of the thrust yield the exact same ${ }^{40} \mathrm{Ar} /{ }^{39} \mathrm{Ar}$ cooling ages (Fig.10). The inferred arrival at mid-crustal levels, as summarised above, fits with the discovery of Latest Cretaceous near-surface arrival as inferred from fission-track reverse thermal modelling (Kydonakis et al., 2014).

We also want to mention that the oldest cooling age recorded in the area is $\sim 125 \mathrm{Ma}$. However, Lips et al. (2000) reported an older spot fusion ${ }^{40} \mathrm{Ar} /{ }^{39} \mathrm{Ar}$ plateau age at $143 \pm 5 \mathrm{Ma}$ from a basement mylonite close to our CR10 sample (Fig.3). Following the above discussion about inheritance and incomplete isotopic reset in the Palaeozoic basement, we suspect that the Jurassic age of Lips et al. (2000) is due to an incomplete reset and should not be interpreted as a cooling age. In fact, this Jurassic age is quite similar to those obtained in this study for incompletely reset biotite from sample (Fig.7f). Our argument for incomplete reset of the micas 
from the basement is strengthened by the existence of an older, almost non-reset, age of $275.3 \pm$ 7.5 Ma obtained a few kilometres to the south (Lips et al., 2000).

As a last note, we highlight the report of identical ${ }^{40} \mathrm{Ar} /{ }^{39} \mathrm{Ar}$ cooling ages (100-125 Ma) from the basement of the Pelagonia domain further to the west (see Figs.1,2) by Lips et al. (1998) and Schermer (1990) which hint for a possible common Cretaceous cooling history between the Pelagonia and Chalkidiki areas. This might also be supported by the documentation of Cretaceous anatectic melts dated at $117 \pm 8$ Ma by Schenker et al. (2015), a date which is close to the age of monazite breakdown $(\sim 132 \mathrm{Ma})$ in the Chalkidiki. However, the late stage low-temperature Cenozoic history between those two areas differ significantly with $>50 \mathrm{Ma}$ apatite fission-track (AFT) ages for the Chalkidiki (Kydonakis et al., 2014) and 25-45 Ma AFT ages for the Pelagonia (see Schenker et al., 2014 for age compilation).

\subsection{Regional geochronology considerations on the Rhodope}

\subsubsection{Rhodope: from the (ultra)high-pressure event to surface arrival}

In the Northern Rhodope Domain (NRD), detailed zircon and monazite dating studies carried out over the last decades have identified a number of distinct metamorphic/magmatic events which are, in turn, often tentatively correlated with large-scale geodynamic processes lacking, however, a general consensus for the evolution model.

The most common zircon metamorphic ages of the early high-pressure metamorphic event recorded in the NRD are Late Jurassic (circa $145 \mathrm{Ma}$ ) and were reported for garnet-kyanite 
gneisses, amphibolitised eclogites and associated paragneisses (e.g., Liati, 2005; Cornelius, 2008; von Quadt et al., 2008; Krenn et al., 2010; Liati et al., 2011). Somewhat older zircon ages from mafic eclogites and related metapelites (Bauer et al., 2007), as well as 160 Ma zircons from migmatitic gneisses that intrude mafic eclogites in the ultrahigh-pressure (UHP) Rhodopean localities (Bonev et al., 2015), have both been used as arguments in favour of a pre-Upper Jurassic age of the (U)HP event. Few circa 75 Ma zircon metamorphic ages from an orthogneisses, a garnet-kyanite gneiss, a garnet-rich mafic rock and an eclogite (Liati et al., 2002; 2011; Bauer et al., 2007) were either attributed to a high-pressure event or related to an amphibolite-facies overprint. These Cretaceous ages are from an upper imbricate unit found in the NRD but due to the limited number of similar metamorphic zircon ages, it is unlikely that this event has a regional importance. Alternatively, these ages could correlate with the Upper Cretaceous magmatism (von Quadt and Peytcheva, 2005; Marchev et al., 2006; Peytcheva et al., 2007; von Quadt et al., 2010). A 126 Ma metamorphic age (Lu/Hf on garnet) was obtained from an upper imbricate unit (Kirchenbaur et al., 2012).

The oldest available EPMA monazite ages from the NRD are reported by Reischmann and Kostopoulos (2002), Hoinkes et al. (2008) and Nagel et al. (2011) who found apparent monazite ages at circa $180 \mathrm{Ma}$ age and attributed monazite formation to the UHP event. In a recent work, Didier et al. (2014) reported, in a detailed study, few monazite cores with similar apparent LA-ICP-MS ages. The same authors, more importantly, reported a wealth of Mesozoic monazite ages that scatter between 115 and 165 Ma for the NRD. They calculated mean ages of $142 \pm 11 \mathrm{Ma}$ and $138 \pm 10 \mathrm{Ma}$ for the two studied localities and attributed the monazite formation to an upper amphibolite/granulite-facies event. Interestingly, our analysis supports the existence of a similar Early Cretaceous amphibolite-facies event recorded in the deepest part of 
the Chalkidiki block (Figs.9a,10) thus linking the peak temperature events between these two Rhodopean domains that were only separated after the Tertiary extension through development of the Southern Rhodope Core Complex (Brun and Sokoutis 2004; 2007; see also Kydonakis et al., 2015b).

On the other hand, Mposkos and Wawrzenitz (1995) provided a $65 \mathrm{Ma}$ age (Rb/Sr) which is indistinguishable from the $62 \mathrm{Ma}$ age (U-Pb on zircon) reported by Liati et al. (2002) both obtained on late pegmatites that crosscut the regional foliation of the gneisses. Both these ages are similar to the $64.4 \pm 1.4 \mathrm{Ma}$ age reported by Bonev et al. (2015) for the rim of a zircon from an orthogneiss. Contrary to the timing of the (U)HP event in the Rhodope, it is commonly accepted that these ages set an absolute minimum for the end of the metamorphic episodes recorded by the Rhodopean gneisses. This is also in agreement with the existence of (i) Maastrichtian - Paleocene deposits that rest on basement gneisses (Boyanov et al., 1982; Goranov and Atanasov, 1992) which further implies that part of the eastern Rhodope was close to the surface by Latest Cretaceous and (ii) Eocene apatite fission-track ages (Kydonakis et al., 2014) which indicate that near surface conditions (temperature less than $120^{\circ} \mathrm{C}$ ) were reached by Latest Cretaceous in the Chalkidiki block at the western end of the Rhodope.

This raises the next question that concerns the thermal history of the Rhodope between peak metamorphic conditions (Jurassic and part of the Cretaceous) and near surface arrival as deduced from the existence of Maastrichtian - Paleocene unconformable deposits and the upper Cretaceous crosscutting pegmatites.

\subsubsection{Medium-temperature geochronology in the Rhodope: filling the Cretaceous gap}


To address the previous question we will present data from the more robust mediumtemperature geochronology system $\left({ }^{40} \mathrm{Ar} /{ }^{39} \mathrm{Ar}\right)$.

In the eastern NRD, the oldest available ${ }^{40} \mathrm{Ar} /{ }^{39} \mathrm{Ar}$ ages are circa $150 \mathrm{Ma}$ from allochthonous orthogneisses (Bonev et al., 2010). However, these ages cannot account for the regional cooling as they pre-date peak conditions experienced by the Rhodopean gneisses (see section 6.2.1). Bonev et al. (2013) reported a $65 \mathrm{Ma}^{40} \mathrm{Ar} /{ }^{39} \mathrm{Ar}$ age from an amphibolite located at the hanging-wall of the Byala Reka - Kechros dome in the eastern Rhodope but the excess argon in the low-temperature steps and the fact that no other similar ages are reported in the area suggest a rather local importance. Mukasa et al. (2003) reported a circa 45 Ma age (amphibole ${ }^{40} \mathrm{Ar} /{ }^{39} \mathrm{Ar}$ ) from a retrogressed eclogite located also at the hanging-wall of the Byala Reka Kechros dome. More importantly, a great number of circa $40 \mathrm{Ma}$ and younger ${ }^{40} \mathrm{Ar} /{ }^{39} \mathrm{Ar}$ ages were obtained from the imbricate units of the NRD and from the exhumed gneiss domes (e.g., Lips et al., 2000; Ovtcharova et al., 2003; Bonev et al., 2006; 2013; Márton et al., 2010). Consequently, this leaves a circa 100 m.y. time lag between the inferred (ultra)high-pressure conditions (roughly constrained at 140-160 Ma) and the event recorded by the ${ }^{40} \mathrm{Ar} /{ }^{39} \mathrm{Ar}$ system (around 45-60 Ma).

Based on regional considerations, the post- $45 \mathrm{Ma}{ }^{40} \mathrm{Ar} /{ }^{39} \mathrm{Ar}$ ages are related to the early Aegean extension and the resultant exhumation of the Rhodopean core complexes rather than cooling of the Rhodopean gneisses after the peak metamorphic episode (see also Burg, 2012; Moulas et al., 2013; Brun et al., 2016). Indeed, severe re-working of the earlier deformation fabrics, exhumation of gneiss domes beneath low-angle detachments (Bonev et al., 2006; Brun and Sokoutis, 2007), extended magmatic activity that includes Latest Cretaceous-Oligocene plutons and Eocene-Oligocene volcanics and hydrothermal deposits (Pal'shin et al., 1975; 
Marchev and Singer, 2002; Marchev et al., 2006; Marchev et al., 2010; Márton et al., 2010; Filipov and Marchev, 2011; Marchev and Filipov, 2012; Kaiser-Rohrmeier et al., 2013), all contributed to an increased thermal gradient in an active region affected by ductile extension and apparently precluded preservation of any pre- 45 Ma medium-temperature isotopic record in the Rhodope. The inferred high thermal gradient is further reflected into the relatively young lowtemperature thermochronology data from the NRD (see review in Kydonakis et al., 2014) and is in line with the existence of numerous Eocene-Oligocene zircon ages from kyanite eclogites, metapelites, metagabbros, biotite gneisses and pegmatites (e.g., Liati and Gebauer 1999; Liati, 2005; Cornelius, 2008; Bosse et al., 2009; Liati et al., 2011; Moulas et al., 2013). The latter zircon ages, instead of representing yet another high-pressure event in the Rhodope should be more likely related, from a geodynamic point of view, to core complex extension coeval with magmatic intrusions of the same age.

Consequently, the post-peak thermal evolution of the NRD can be addressed using the record of the Chalkidiki gneisses. Based on our new findings and on the detailed mediumtemperature geochronology record obtained in the Chalkidiki block, we can safely propose that the Rhodopean gneisses arrived at mid-crustal levels by the early Late Cretaceous shortly after the regional amphibolite-facies overprint that occurred during the Early Cretaceous. Although the evidence for the early Late Cretaceous arrival at mid-crustal levels is completely erased in the NRD due to the effects of the Tertiary extension, it is clearly preserved in the Chalkidiki block that largely escaped the Tertiary thermal perturbation.

\section{Conclusions}


Prior to their separation by the exhumation of the Southern Rhodope Core complex in Eocene, the Chalkidiki block and the Northern Rhodope Domain underwent the same tectonothermal history. We studied rock samples exposed at various structural positions within the Chalkidiki metamorphic pile in order to define the Mesozoic post-peak metamorphic evolution of the North Aegean. Based on the available literature data from the Northern Rhodope Domain and our data from the Chalkidiki block, a schematic P-T-t diagram is compiled in Fig.11. Our contribution to the evolution of the North Aegean can be summarised in two main points:

(1) The regional amphibolite-facies re-equilibration occurred in all probability at (or slightly before) $132 \mathrm{Ma}$ based on U-Th-Pb LA-ICP-MS dating of monazites from a garnetkyanite micaschist exposed at the deepest (eastern) part of the Chalkidiki block (Fig.10). The conclusion is based on isotopic reset of primary Carboniferous - Early Triassic monazite grains coeval with partial monazite destruction, REE-mobilisation and formation of a corona made of apatite, allanite and epidote. The suggested timing for the amphibolite-facies overprint (this study) is contemporaneous within error with the age proposed recently for the central/north Rhodope based on monazite dating (circa 140 Ma; Didier et al., 2014) thus, linking the Cretaceous history of the Chalkidiki block with the imbricates of the Northern Rhodope Domain further to the northeast.

(2) Based on the results of ${ }^{40} \mathrm{Ar} /{ }^{39} \mathrm{Ar}$ step-heating on micas, cooling and arrival at midcrustal levels occurred at 95-100 Ma for the eastern and structurally lower parts of the Chalkidiki block whereas, the western, and structurally uppermost part of the system went through the same event at 120-125 Ma. (Fig.10). We propose that syn-metamorphic thrusting must have ceased in the Chalkidiki block by early Late Cretaceous as inferred from the existence of virtually identical ${ }^{40} \mathrm{Ar} /{ }^{39} \mathrm{Ar}$ cooling ages on both the hanging-wall and foot-wall of a major thrust that separates an 
upper basement slice from a lower basement-cover complex (Fig.10). The obtained 120-125 Ma ages are similar to the ${ }^{40} \mathrm{Ar} /{ }^{39} \mathrm{Ar}$ cooling ages documented from the basement of the Pelagonia domain further to the west (e.g., Schermer, 1990; Lips et al., 1998). Juxtaposition of the "120$125 \mathrm{Ma}$ " to the "95-100 Ma" subdomains of the Chalkidiki block occurred during the Tertiary extensional phase (Fig.10).

Having largely escaped thermal perturbations related to the Tertiary extension, the Chalkidiki block maintained a rather complete isotopic record from the amphibolite-facies overprint (at or slightly before $132 \mathrm{Ma}$; this study), through the greenschist-facies (95-125 Ma; this study) to near surface arrival (65 Ma; Kydonakis et al., 2014). These new findings adequately fill the Cretaceous lack of medium-temperature geochronology data in the area.

\section{ACKNOWLEDGMENTS}

This work was funded by the European Union FP7 Marie Curie ITN "TOPOMOD” contract 264517. KK is grateful to Dimitrios Kostopoulos for introduction to the geology of the Rhodope and for stimulating discussions and numerous fieldtrips over the last years. Frédéric Lecoeur (Géosciences Montpellier) is thanked for valuable help during the argon/argon analyses and Xavier Le Coz (Géosciences Rennes) for the thin sections preparation. The comments received by Nikolay Bonev and Filippo Schenker materially helped to improve the original manuscript and are greatly appreciated. Philippe Agard is greatly acknowledged for editorial handling. 


\section{REFERENCES}

Agard, P., Monié, P., Jolivet, L., \& Goffé, B., 2002. Exhumation of the Schistes lustres complex: in situ laser probe ${ }^{40} \mathrm{Ar} /{ }^{39} \mathrm{Ar}$ constraints and implications for the Western Alps, Journal of Metamorphic Geology, 20(6), 599 - 618.

Asvesta, A., 1992. Magmatism and associated sedimentation during the first stage of the opening of the Vardar oceanic basin in Triassic times (in greek with english abstract), Ph.D. thesis, University of Thessaloniki, Greece.

Asvesta, A. \& Dimitriadis, S., 2010. Facies architecture of a Triassic rift-related Silicic VolcanoSedimentary succession in the Tethyan realm, Peonias subzone, Vardar (Axios) Zone, northern Greece; Regional implications, Journal of Volcanology and Geothermal Research, 193(3 - 4), $245-269$.

Augier, R., Agard, P., Monié, P., Jolivet, L., Robin, C., \& Booth-Rea, G., 2005. Exhumation, doming and slab retreat in the Betic Cordillera (SE Spain): in situ ${ }^{40} \mathrm{Ar} /{ }^{39} \mathrm{Ar}$ ages and P-T-d-t paths for the Nevado-Filabride complex, Journal of Metamorphic Geology, 23(5), 357 - 381.

Ballouard, C., Boulvais, P., Poujol, M., Gapais, D., Yamato, P., Tartese, R., \& M., C., 2015. Tectonic record, magmatic history and hydrothermal alteration in the Hercynian Guerande leucogranite, Armorican Massif, France, Lithos, 220 - 223, 1 - 22.

Bauer, C., Rubatto, D., Krenn, K., Proyer, A., \& Hoinkes, G., 2007. A zircon study from the Rhodope metamorphic complex, N-Greece: Time record of a multistage evolution, Lithos, 99(3 4), $207-228$. 
Bonev, N., Burg, J.-P., \& Ivanov, Z., 2006. Mesozoic-Tertiary structural evolution of an extensional gneiss dome - the Kesebir-Kardamos dome, eastern Rhodope (Bulgaria-Greece), International Journal of Earth Sciences (Geologische Rundschau), 95(2), 318 - 340.

Bonev, N., Spikings, R., Moritz, R., \& Marchev, P., 2010. The effect of early Alpine thrusting in late-stage extensional tectonics: Evidence from the Kulidzhik nappe and the Pelevun extensional allochthon in the Rhodope Massif, Bulgaria, Tectonophysics, 488(1 - 4), 256 - 281.

Bonev, N., Spikings, R., Moritz, R., Marchev, P., \& D., C., 2013. ${ }^{40} \mathrm{Ar} /{ }^{39} \mathrm{Ar}$ age constraints on the timing of Tertiary crustal extension and its temporal relation to ore-forming and magmatic processes in the Eastern Rhodope Massif, Bulgaria, Lithos, 180 - 181, 264 - 278.

Bonev, N., Marchev, P., Moritz, R., \& Collings, D., 2015. Jurassic subduction zone tectonics of the Rhodope Massif in the Thrace region (NE Greece) as revealed by new U-Pb and ${ }^{40} \mathrm{Ar} /{ }^{39} \mathrm{Ar}$ geochronology of the Evros ophiolite and high-grade basement rocks. Gondwana Research, 27, $760-775$.

Borsi, S., Ferrara, G., \& Mercier, J., 1965. Determination de l'âge des series metamorphiques du Massif Serbomacedonien au Nord-Est de Thessalonique (Grèce) par les methodes $\mathrm{Rb} / \mathrm{Sr}$ et K/Ar, Annales de la Societe geologique du Nord, 84, 223 - 225.

Bosse, V., Boulvais, P., Gautier, P., Tiepolo, M., Ru et, G., Devidal, J., Cherneva, Z., Gerdjikov, I., \& Paquette, J., 2009. Fluid-induced disturbance of the monazite Th-Pb chronometer: In situ dating and element mapping in pegmatites from the Rhodope (Greece, Bulgaria), Chemical Geology, 261(3 - 4), 286 - 302. 
Bosse, V., Cherneva, Z., Gautier, P., \& Gerdjikov, I., 2010. Two partial melting events as recorded by the U-Th-Pb chronometer in monazite: LA-ICPMS in situ dating in metapelites from the Bulgarian Central Rhodopes, Geologica Balcanica, 39(1 - 2), 51 - 52.

Boyanov, I., Ruseva, M., \& Dimitrova, E., 1982. First find of Upper-Cretaceous foraminifers in East-Rhodopes, Geologica Balcanica, 12(4), 20.

Broska, I. \& Siman, P., 1998. The breakdown of monazite in the west-Carpathian Veporic orthogneisses and Tatric granites, Geologica Carpathica, 49(3), 161 - 167.

Brun, J.-P. \& Sokoutis, D., 2004. North Aegean extension: from the Rhodope core com-plex to Neogene basins., in Proceedings of the 5th International Symposium of Eastern Mediterranean Geology, Thessaloniki, Greece, 14-20 April 2004 , vol. 1, pp. 49 - 52.

Brun, J.-P. \& Sokoutis, D., 2007. Kinematics of the Southern Rhodope Core Complex (North Greece), International Journal of Earth Sciences (Geologische Rundschau), 96(6), 1079 - 1099.

Brun, J.-P. \& Sokoutis, D., 2010. 45 m.y. of Aegean crust and mantle flow driven by trench retreat, Geology, 38(9), $815-818$.

Brun, J.-P., Faccenna, C., Gueydan, F., Sokoutis, D., Philippon, M., Kydonakis, K. \& Gorini, C., 2016. The two-stage Aegean extension, from lacolized to distributed, a result of slab rollback acceleration, accepted for publication in Canadian Journal of Earth Sciences.

Budzyn, B., Harlov, D. E., Williams, M. L., \& Jercinovic, M. J., 2011. Experimental determination of stability relations between monazite, fluorapatite, allanite, and REE-epidote as a function of pressure, temperature, and fluid composition, American Mineralogist, 96(10), 1547 1567. 
Burg, J.-P., 2012. Rhodope: From Mesozoic convergence to Cenozoic extension. Review of petro-structural data in the geochronological frame, Journal of the Virtual Explorer, 42(1).

Burg, J.-P., Ivanov, Z., Ricou, L.-E., Dimov, D., \& Klain, L., 1990. Implications of shear-sense criteria for the tectonics evolution of the Central Rhodope massif, southern Bulgaria, Geology, $18,451-454$.

Burg, J.-P., Godfriaux, I., \& Ricou, L.-E., 1995. Extension of the Mesozoic Rhodope thrust units in the Vertiskos-Kerdilion Massifs, Comptes Rendus de l'Académie des Sciences, Paris, 320(IIa), $889-896$.

Burg, J.-P., Ricou, L.-E., Ivanov, Z., Godfriaux, I., Dimov, D., \& Klain, L., 1996. Synmetamorphic nappe complex in the Rhodope Massif. Structure and kinematics, Terra Nova, 8(1), $6-15$.

Christo des, G., Koroneos, A., Pe-Piper, G., Katirtzoglou, K., \& Chatzikirkou, A., 1999. PreTertiary A-Type magmatism in the Serbomacedonian massif (N. Greece): Kerkini granitic complex, Bulletin of the Geological Society of Greece, XXXIII, 131 - 148.

Cornelius, N. K., 2008. UHP metamorphic rocks of the Eastern Rhodope Massif, NE Greece: new constraints from petrology, geochemistry and zircon ages, Ph.D. thesis, Johannes Gutenberg-Universität Mainz.

de Wet, A. P., Miller, J. A., Bickle, M. J., \& Chapman, H. J., 1989. Geology and geochronol-ogy of the Arnea, Sithonia and Ouranopolis intrusions, Chalkidiki Peninsula, northern Greece, Tectonophysics, 161(1 - 2), 65 - 79. 
Didier, A., Bosse, V., Cherneva, Z., Gautier, P., Georgieva, M., Paquette, J. L., \& Gerd-jikov, I., 2014. Syn-deformation fluid-assisted growth of monazite during renewed high-grade metamorphism in metapelites of the Central Rhodope (Bulgaria, Greece), Chemical Geology, $381,206-222$.

Dinter, D. A. \& Royden, L., 1993. Late Cenozoic extension in northeastern Greece: Strymon Valley detachment system and Rhodope metamorphic core complex, Geology, 21, 45 - 48.

Dinter, D. A., Macfarlane, A., Hames, W., Isachsen, C., Bowring, S., \& Royden, L., 1995. U-Pb and ${ }^{40} \mathrm{Ar} /{ }^{39} \mathrm{Ar}$ geochronology of the Symvolon granodiorite: Implications for the thermal and structural evolution of the Rhodope metamorphic core complex, northeastern Greece, Tectonics, 14(4), 886 - 908.

Dixon, J. E. \& Dimitriadis, S., 1984. Metamorphosed ophiolitic rocks from the SerboMacedonian Massif, near Lake Volvi, North-east Greece, Geological Society, London, Spe-cial Publications, 17, 603 - 618.

Eglinger, A., Tarantola, A., Durand, C., Ferraina, C., Vanderhaeghe, O., André-Mayer, A.-S., Paquette, J. L., \& Deloule, E., 2014. Uranium mobilization by fluids associated with $\mathrm{Ca}-\mathrm{Na}$ metasomatism: A P-T-t record of fluid-rock interactions during Pan-African metamorphism (Western Zambian Copperbelt), Chemical Geology, 386, 218 - 237.

Eleftheriadis, G., Frank, W., \& Petrakakis, K., 2001. ${ }^{40} \mathrm{Ar} /{ }^{39} \mathrm{Ar}$ dating and cooling history of the Pangeon granitoids, Rhodope Massif (eastern Macedonia, Greece), Bulletin of the Geological Society of Greece, XXXIV(3), 911 - 916. 
Filipov, P. \& Marchev, P., 2011. U-Pb zircon and ${ }^{40} \mathrm{Ar} /{ }^{39} \mathrm{Ar}$ ages of Mesta volcanic rocks and Central Pirin pluton, in Bulgarian National Conference "GEOSCIENCES 2011".

Finger, F., Broska, I., Roberts, M. P., \& Schermaier, A., 1998. Replacement of primary monazite by apatite-allanite-epidote coronas in an amphibolite facies granite gneiss from the eastern Alps, American Mineralogist, 83(3 - 4), 248 - 258.

Frei, D., 1996. The extent of inter-mineral isotope equilibrium: a systematic bulk $\mathrm{U}-\mathrm{Pb}$ and $\mathrm{Pb}$ step leaching $(\mathrm{PbSL})$ isotope study of individual minerals from the Tertiary granite of Jerissos (northern Greece), European Journal of Mineralogy, 8, 1175 - 1189.

Gasquet, D., Bertrand, J.-M., Paquette, J.-L., Lehmann, J., Ratzov, G., Guedes, R. D. A., Tiepolo, M., Boullier, A.-M., Scaillet, S., \& Nomade, S., 2010. Miocene to Messinian deformation and hydrothermal activity in a pre-Alpine basement massif of the French western Alps: new U-Th- $\mathrm{Pb}$ and argon ages from the Lauziere massif, Bulletin de la Societ Geologique de France, 181(3), 227 - 241.

Gautier, P., Brun, J.-P., Moriceau, R., Sokoutis, D., Martinod, J., \& Jolivet, L., 1999. Timing, kinematics and cause of Aegean extension: a scenario based on a comparison with simple analogue experiments, Tectonophysics, 315, 31 - 72 .

Gerdjikov, I. \& Milev, P., 2005. Nestos Shear Zone and structure of the metamorphic basement in the area south of Mesta graben, Comptes Rendus de l'Academie Bulgare des Sciences, 58(2), $197-204$.

Goranov, A. \& Atanasov, G., 1992. Lithostratigraphy and formation conditions of MaastrichtianPaleocene deposits in Krumovgrad District, Geologica Balcanica, 22(3), 71 - 82. 
Harre, W., Kockel, F., Kreuzer, H., Lenz, H., M•uller, P., \& Walther, H. W., 1968. Uber Rejuvenationen im Serbo-Madzedonischen Massiv (Deutung radiometrischer Altersbestimmungen), in XXIII International Geological Congress, vol. 6, pp. 223 - 236.

Harrison, T. M., Duncan, I., \& McDougall, I., 1985. Diffusion of ${ }^{40} \mathrm{Ar}$ in biotite: Temperature, pressure and compositional effects, Geochimica et Cosmochimica Acta, 49(11), 2461 - 2468.

Harrison, T. M., Célérier, J., Aikman, A. B., Hermann, J., \& Heizler, M. T., 2009. Diffusion of ${ }^{40} \mathrm{Ar}$ in muscovite, Geochimica et Cosmochimica Acta, 73(4), 1039 - 1051.

Himmerkus, F., Reischmann, T., \& Kostopoulos, D., 2006. Late Proterozoic and Silurian basement units within the Serbo-Macedonian Massif, northern Greece: the significance of terrane accretion in the Hellenides, Geological Society, London, Special Publications, 260, 35 - 50.

Himmerkus, F., Anders, B., Reischmann, T., \& Kostopoulos, D., 2007. Gondwana-derived terranes in the northern Hellenides, The Geological Society of America Memoir, 200, 379 - 390.

Himmerkus, F., Reischmann, T., \& Kostopoulos, D., 2009a. Serbo-Macedonian revisited: A Silurian basement terrane from northern Gondwana in the Internal Hellenides, Greece, Tectonophysics, 473(1 - 2), 20 - 35.

Himmerkus, F., Reischmann, T., \& Kostopoulos, D., 2009b. Triassic rift-related meta-granites in the Internal Hellenides, Greece, Geological Magazine, 146(2), 252 - 265.

Hoinkes, G., Krenn, E., Rubatto, D., Krenn, K., Proyer, A., Bernhard, F., \& Bauer, C., 2008. Timing the Rhodope UHP-event using zircon and monazite, in 33rd International Geological Congress. UHP-04 Ultra-high pressure metamorphism: Mineral reactions, geo-chemistry, thermobarometry and geochronology. 
Jackson, S. E., Pearson, N. J., Griffin, W. L., \& Belousova, E. A., 2004. The application of laser ablation-inductively coupled plasma-mass spectrometry to in situ U-Pb zircon geochronology, Chemical Geology, 211(1 - 2), 47 - 69.

Jahn-Awe, S., Froitzheim, N., Nagel, T. J., Frei, D., Georgiev, N., \& Pleuger, J., 2010. Structural and geochronological evidence for Paleogene thrusting in the western Rhodopes, SW Bulgaria: Elements for a new tectonic model of the Rhodope Metamorphic Province, Tectonics, 29, TC3008.

Janak, M., Froitzheim, N., Georgiev, N., Nagel, T. J., \& Sarov, S., 2011. P-T evolution of kyanite eclogite from the Pirin Mountains (SW Bulgaria): implications for the Rhodope UHP Metamorphic Complex, Journal of Metamorphic Geology, 29(3), 317 - 332.

Jolivet, L. \& Brun, J.-P., 2010. Cenozoic geodynamic evolution of the Aegean, International Journal of Earth Sciences (Geologische Rundschau), 99(1), 109 - 138.

Jolivet, L. \& Faccenna, C., 2000. Mediterranean extension and the Africa-Eurasia collision, Tectonics, 19(6), 1095 - 1106.

Jones, C. E., Tarney, J., Baker, J. H., \& Gerouki, F., 1992. Tertiary granitoids of Rhodope, northern Greece: magmatism related to extensional collapse of the Hellenic Orogen?, Tectonophysics, 210(3 - 4), 295 - 314.

Jourdan, F. \& Renne, P. R., 2007. Age calibration of the Fish Canyon sanidine ${ }^{40} \mathrm{Ar} /{ }^{39} \mathrm{Ar}$ dating standard using primary K-Ar standards, Geochimica et Cosmochimica Acta, 71(2), 387 - 402.

Kaiser-Rohrmeier, M., von Quadt, A., Driesner, T., Heinrich, C. A., Handler, R., Ovtcharova, M., Ivanov, Z., Petrov, P., Sarov, S., \& Peytcheva, I., 2013. Post-Orogenic Ex-tension and 
Hydrothermal Ore Formation: High-Precision Geochronology of the Central Rhodopian Metamorphic Core Complex (Bulgaria-Greece), Economic Geology, 108(4), 691 - 718.

Kauffmann, G., Kockel, F., \& Mollat, H., 1976. Notes on the stratigraphic and paleogeographic position of the Svoula Formation in the Innermost Zone of the Hellenides (Northern Greece), Bulletin de la Société Géologique de France, 7(2), 225 - 230.

Kaufman, P. S., 1995. Extensional Tectonic History of the Rhodope Metamorphic Core Complex, Greece and Geophysical Modeling of the Halloran Hills, California, Ph.D. thesis, Massachusetts Institute of Technology.

Kilias, A., Falalakis, G., \& Mountrakis, D., 1999. Cretaceous-Tertiary structures and kinematics of the Serbomacedonian metamorphic rocks and their relation to the exhumation of the Hellenic hinterland (Macedonia, Greece), International Journal of Earth Sciences (Geologische Rundschau), 88(3), 513 - 531.

Kirchenbaur, M., Pleuger, J., Jahn-Awe, S., Nagel, T. J., Froitzheim, N., Fonseca, R. O. C., \& Münker, C., 2012. Timing of high-pressure metamorphic events in the Bulgarian Rhodopes from Lu-Hf garnet geochronology, Contributions to Mineralogy and Petrology, 163(5), 897 - 921.

Kockel, F. \& Mollat, H., 1977. Geological map of the Chalkidiki peninsula and adjacent areas (Greece), Scale 1: 100000, Bundesanstalt für Geowissenschaften und Rohstoffe, Hannover.

Kockel, F., Mollat, H., \& Walther, H. W., 1971. Geologie des Serbe-Mazedonischen Massivs und seines mesozoischen Rahmens (Nordgriechenland), Geologisches Jahrbuch, 89(1), 529 551. 
Kockel, F., Mollat, H., \& Walther, H., 1977. Erlauterungen zur Geologischen Karte der Chalkidiki und angrenzender Gebiete, Bundesanstalt für Geowissenschaften und Rohstoffe, Hannover, $119 \mathrm{pp}$.

Kolocotroni, C. \& Dixon, J. E., 1991. The origin and emplacement of the Vrondou granite, Serres, NE Greece, Bulletin of the Geological Society of Greece, XXV(1), 469 - 483.

Kondopoulou, D. \& Westphal, M., 1986. Paleomagnetism of the Tertiary intrusives from Chalkidiki (northern Greece), Journal of Geophysics, 59, 62 - 66.

Krenn, E., Harlov, D. E., Finger, F., \& Wunder, B., 2012. LREE-redistribution among fluorapatite, monazite, and allanite at high pressures and temperatures, American Mineralogist, $97(11-12), 1881-1890$.

Kronberg, P., Meyer, W., \& Pilger, A., 1970. Geologie der Rila-Rhodope-Masse zwischen Strimon und Nestos (Nordgriechenland), Beihefte Geologisches Jahrbuch, 88, 133 - 180.

Kydonakis, K., Gallagher, K., Brun, J.-P., Jolivet, M., Gueydan, F., \& Kostopoulos, D., 2014. Upper Cretaceous exhumation of the western Rhodope Metamorphic Province (Chalkidiki Peninsula, northern Greece), Tectonics, 33, 1113 - 1132.

Kydonakis, K., Brun, J.-P., \& Sokoutis, D., 2015a. North Aegean core complexes, the gravity spreading of a thrust wedge, Journal of Geophysical Research: Solid Earth, 120(1), 595 - 616.

Kydonakis, K., Brun, J.-P., Sokoutis, D., \& Gueydan, F., 2015b. Kinematics of Cretaceous subduction and exhumation in the western Rhodope (Chalkidiki block), Tectonophysics, 665, $218-235$. 
Kydonakis, K., Moulas, E., Chatzitheodoridis, E., Brun, J.-P., \& Kostopoulos, D., 2015c. Firstreport on Mesozoic eclogite-facies metamorphism preceding Barrovian overprint from the western Rhodope (Chalkidiki, northern Greece), Lithos, 220 - 223, 147 - 163.

Liati, A., 2005. Identification of repeated Alpine (ultra) high-pressure metamorphic events by U$\mathrm{Pb}$ SHRIMP geochronology and REE geochemistry of zircon: the Rhodope zone of Northern Greece, Contributions to Mineralogy and Petrology, 150(6), 608 - 630.

Liati, A. \& Gebauer, D., 1999. Constraining the prograde and retrograde P-T-t path of Eocene HP rocks by SHRIMP dating of different zircon domains: inferred rates of heating, burial, cooling and exhumation for central Rhodope, northern Greece, Contributions to Mineralogy and Petrology, 135(4), 340 - 354.

Liati, A. \& Seidel, E., 1996. Metamorphic evolution and geochemistry of kyanite eclogites in central Rhodope, northern Greece, Contributions to Mineralogy and Petrology, 123(3), 293 307.

Liati, A., Gebauer, D., \& Wysoczanski, R., 2002. U-Pb SHRIMP-dating of zircon domains from UHP garnet-rich ma c rocks and late pegmatoids in the Rhodope zone (N Greece); evidence for Early Cretaceous crystallization and Late Cretaceous metamorphism, Chemical Geology, 184(3 4), 281 - 299.

Liati, A., Gebauer, D., \& Fanning, C. M., 2011. Ultrahigh-Pressure Metamorphism: 25 Years After the Discovery of Coesite and Diamond, chap. Geochronology of the Alpine UHP Rhodope Zone: A Review of Isotopic Ages and Constraints on the Geodynamic Evolution, pp. 295 - 324, Elsevier Inc. 
Lips, A. L. W., White, S. H., \& Wijbrans, J. R., 1998. ${ }^{40} \mathrm{Ar} /{ }^{39} \mathrm{Ar}$ Laserprobe direct dating of discrete deformational events: a continuous record of early Alpine tectonics in the Pelagonian Zone, NW Aegean area, Greece, Tectonophysics, 298, 133-153.

Lips, A. L. W., White, S. H., \& Wijbrans, J. R., 2000. Middle-Late Alpine thermotectonic evolution of the southern Rhodope Massif, Greece, Geodinamica Acta, 13, 281 - 292.

Ludwig, K. R., 2001. Isoplot/Ex rev. 2.49, Berkeley. California, Berkeley Geochronology Center, Special Publication, A(1), 56.

Majka, J. \& Budzy, B., 2006. Monazite breakdown in metapelites from Wedel Jarlsberg Land, Svalbard - Preliminary report, Mineralogia Polonica, 37(1), 61 - 68.

Marakis, G., 1969. Geochronology of granites from Macedonia (Greece) (in greek), Annales Géologiques des Pays Helléniques, 21, 121 - 152.

Marchev, P. \& Filipov, P., 2012. First findings of Late Cretaceous magmatic rocks in the Pirin Mts, in Bulgarian National Conference "GEOSCIENCES 2012".

Marchev, P. \& Singer, B., 2002. ${ }^{40} \mathrm{Ar} /{ }^{39} \mathrm{Ar}$ geochronology of magmatism and hydrothermal activity of the Madjarovo base-precious metal ore district, eastern Rhodopes, Bulgaria, Geological Society, London, Special Publications, 204, 137 - 150.

Marchev, P., Raicheva, R., Downes, H., Vaselli, O., Chiaradia, M., \& Moritz, R., 2004. Compositional diversity of Eocene-Oligocene basaltic magmatism in the Eastern Rhodopes, SE Bulgaria: implications for genesis and tectonic setting, Tectonophysics, 393(1 - 4), 301 - 328. 
Marchev, P., von Quadt, A., Peytcheva, I., \& Ovtcharova, M., 2006. The age and origin of the Chuchuliga and Rozino granites, Eastern Rhodopes, in Bulgarian National Conference "GEOSCIENCES 2006".

Marchev, P., Kibarov, P., Spikings, R., Ovtcharova, M., Marton, I., \& Moritz, R., 2010. ${ }^{40} \mathrm{Ar} /{ }^{39} \mathrm{Ar}$ and $\mathrm{U}-\mathrm{Pb}$ geochronology of the Iran Tepe volcanic complex, Eastern Rhodopes, Geologica Balcanica, 39(3), 3 - 12.

Marchev, P., Georgiev, S., Raicheva, R., Peytcheva, I., von Quadt, A., Ovtcharova, M., \& Bonev, N., 2013. Adakitic magmatism in post-collisional setting: An example from the EarlyMiddle Eocene Magmatic Belt in Southern Bulgaria and Northern Greece, Lithos, 180 - 181, 159 $-180$.

Márton, I., Moritz, R., \& Spikings, R., 2010. Application of low-temperature thermochronology to hydrothermal ore deposits: Formation, preservation and exhumation of epithermal gold systems from the Eastern Rhodopes, Bulgaria, Tectonophysics, 483(3-4), 240 - 254.

Meinhold, G. \& Kostopoulos, D. K., 2013. The Circum-Rhodope Belt, northern Greece: Age, provenance, and tectonic setting, Tectonophysics, 595 - 596, 55 - 68.

Michard, A., Goffé, B., Liati, A., \& Mountrakis, D., 1994. Decouverte du facies schiste bleu clans les nappes du Circum-Rhodope: un element d'une ceinture HP-BT eohellenique en Grece septentrionale?, Comptes Rendus de l'Académie des Sciences, Paris, 318(2), 1535 - 1542.

Moulas, E., Kostopoulos, D., Connolly, J. A. D., \& Burg, J.-P., 2013. P-T Estimates and Timing of the Sapphirine-Bearing Metamorphic Overprint in Kyanite Eclogites from Central Rhodope, Northern Greece, Petrology, 21(5), 507 - 521. 
Mposkos, E. \& Liati, A., 1993. Metamorphic evolution of metapelites in the high-pressure terrane of the Rhodope Zone, Northern Greece, Canadian Mineralogist, 31, 401 - 424.

Mposkos, E. \& Wawrzenitz, N., 1995. Metapegmatites and pegmatites bracketing the time of HP-metamorphism in polymetamorphic rocks of the E-Rhodope, N. Greece: petrological and geochronological constraints, Geological Society of Greece Special Publications, 4, 602 - 608.

Mposkos, E. D. \& Kostopoulos, D. K., 2001. Diamond, former coesite and supersilicic garnet in metasedimentary rocks from the Greek Rhodope: a new ultrahigh-pressure metamorphic province established, Earth and Planetary Science Letters, 192(4), 497 - 506.

Mukasa, S. B., Haydoutov, I., Carrigan, C. W., \& Kolcheva, K., 2003. Thermobarometry and ${ }^{40} \mathrm{Ar} /{ }^{39} \mathrm{Ar}$ ages of eclogitic and gneissic rocks in the Sredna Gora and Rhodope terranes of Bulgaria, Journal of the Czech Geological Society, 48(1 - 2), 94 - 95.

Nagel, T. J., Schmidt, S., Janak, M., Froitzheim, N., Jahn-Awe, S., \& Georgiev, N., 2011. The exposed base of a collapsing wedge: The Nestos Shear Zone (Rhodope Metamorphic Province, Greece), Tectonics, 30, TC4009.

Ovtcharova, M., von Quadt, A., Heinrich, C. A., Frank, M., Kaiser-Rohrmeier, M., Peycheva, I., \& Cherneva, Z., 2003. Triggering of hydrothermal ore mineralization in the Central Rhodopean Core Complex (Bulgaria) - Insight from isotope and geochronological studies on tertiary magmatism and migmatization, in 7th Biennial Meeting, Society for Geology Applied to Mineral Deposits, Mineral exploration and sustainable development, pp. 367 - 370, Millpress, Rotterdam. 
Pal'shin, I., Simov, S. D., Arakelyants, M., \& Chernyshev, I., 1975. Absolute age of Alpine activations in Rhodope median massif, Bulgaria, International Geology Review, 17(10), 1161 1168.

Papadopoulos, C. \& Kilias, A., 1985. Altersbeziehungen zwischen Metamorphose und Deformation im zentralen Teil des Serbomazedonischen Massivs (Vertiskos Gebirge, NordGriechenland), Geologische Rundschau, 74(1), 77 - 85.

Papanikolaou, D., 2009. Timing of tectonic emplacement of the ophiolites and terrane paleogeography in the Hellenides, Lithos, 108(1 - 4), 262 - 280.

Papanikolaou, D. \& Panagopoulos, A., 1981. On the structural style of southern Rhodope, Greece, Geologica Balcanica, 11(3), 13 - 22.

Papanikolaou, D. J., 2013. Tectonostratigraphic models of the Alpine terranes and subduction history of the Hellenides, Tectonophysics, 595 - 596, 1 - 24.

Paquette, J. \& Tiepolo, M., 2007. High resolution (5 microns) U-Th-Pb isotope dating of monazite with excimer laser ablation (ELA)-ICPMS, Chemical Geology, 240(3 - 4), 222 - 237.

Perraki, M., Proyer, A., Mposkos, E., Kaindl, R., \& Hoinkes, G., 2006. Raman microspectroscopy on diamond, graphite and other carbon polymorphs from the ultrahigh-pressure metamorphic Kimi Complex of the Rhodope Metamorphic Province, NE Greece, Earth and Planetary Science Letters, 241(3 - 4), 672 - 685.

Peytcheva, I., Kostitsin, Y., Salnikova, E., Kamenov, B., \& Klain, L., 1998. Rb-Sr and U-Pb isotope data for the Rila-Rhodope batholith (in bulgarian with english abstract), Geochemistry, Mineralogy and Petrology, 35, 93 - 105. 
Peytcheva, I., von Quadt, A., Naydenov, K., Sarov, S., Dimov, D., \& Voinova, E., 2007. U-Pb zircon-xenotime-monazite dating and Hf-isotope tracing to distinguish Cretaceous and Paleogene granitoids in the Western Rhodopes and Rila Mountain, in Bulgarian National Conference "GEOSCIENCES 2007".

Poitrasson, F., Chenery, S., \& Bland, D. J., 1996. Contrasted monazite hydrothermal al-teration mechanisms and their geochemical implications, Earth and Planetary Science Letters, 145(1 - 4), $79-96$.

Reischmann, T. \& Kostopoulos, D., 2002. Timing of UHPM in metasediments from the Rhodope Massif, N Greece, in Goldschmidt Conference Abstracts, no. A634.

Ricou, L.-E., 1965. Contribution à l'etude geologique de la bordure sud-ouest du Massif Serbomacedonien aux environs de Salonique, Ph.D. thesis, Universit de Paris.

Ricou, L.-E., Burg, J.-P., Godfriaux, I., \& Ivanov, Z., 1998. Rhodope and Vardar: the metamorphic and the olistostromic paired belts related to the Cretaceous subduction under Europe, Geodinamica Acta, 11(6), 285 - 309.

Robertson, A. H., 2002. Overview of the genesis and emplacement of Mesozoic ophiolites in the Eastern Mediterranean Tethyan region, Lithos, 65(1 - 2), 1 - 67.

Sakellariou, D. \& Dürr, S., 1993. Geological structure of the Serbo-Macedonian massif in NE Chalkidiki peninsula (in greek with english abstract), Bulletin of the Geological Society of Greece, XXVIII(1), 179 - 193. 
Schenker, F. L., Burg, J. P., Kostopoulos, D., Moulas, E., Larionov, A., \& Quadt, A., 2014. From Mesoproterozoic magmatism to collisional Cretaceous anatexis: Tectonomagmatic history of the Pelagonian Zone, Greece, Tectonics, 33(8), 1552 - 1576.

Schenker, F. L., M. G. Fellin, \& J.-P. Burg, 2014. Polyphase evolution of Pelagonia (northern Greece) revealed by geological and fission-track data, Solid Earth Discussions 6.2 (2014): 3075 3109.

Schermer, E. R., 1990. Mechanisms of blueschist creation in preservation in an A-type subduction zone, Mount Olympos region, Greece, Geology, 18, 1130 - 1133.Schmidt, S., Nagel, T. J., \& Froitzheim, N., 2010. A new occurrence of microdiamond-bearing metamorphic rocks, SW Rhodopes, Greece, European Journal of Mineralogy, 22, 189 - 198.

Seydoux-Guillaume, A. M., Paquette, J. L., Wiedenbeck, M., Montel, J. M., \& Heinrich, W., 2002. Experimental resetting of the U-Th-Pb systems in monazite, Chemical Geology, 191(1 3), $165-181$.

Siivola, J., Schmid, R., 2007. Systematic Nomenclature for Metamorphic Rocks. 12. List of Mineral Abbreviations. Recommendations by the IUGS Subcommission on the Systematics of Metamorphic Rocks. www.bgs.ac.uk/scmr/docs/papers/paper_12.pdf.

Snel, E., Marunteanu, M., \& Meulenkamp, J. E., 2006. Calcareous nannofossil biostratigraphy and magnetostratigraphy of the Upper Miocene and Lower Pliocene of the Northern Aegean (Orphanic Gulf-Strimon Basin areas), Greece, Palaeogeography, Palaeoclimatology, Palaeoecology, 238, 125 - 150. 
Sokoutis, D., Brun, J.-P., van den Driessche, J., \& Pavlides, S., 1993. A major Oligo-Miocene detachment in southern Rhodope controlling north Aegean extension, Journal of the Geological Society, London, 150, 243 - 246.

Soldatos, T., Koroneos, A., Christo des, G., \& Moro, A. D., 2001. Geochronology and origin of the Elatia plutonite (Hellenic Rhodope Massif, N. Greece) constrained by new Sr isotopic data, N. Jb. Miner. Abh., 176(2), 179 - 209.

Turpaud, P. \& Reischmann, T., 2010. Characterisation of igneous terranes by zircon dating: implications for UHP occurrences and suture identification in the Central Rhodope, northern Greece, International Journal of Earth Sciences (Geologische Rundschau), 99(3), 567 - 591.

van Hinsbergen, D. J. J., Hafkenscheid, E., Spakman, W., Meulenkamp, J. E., \& Wortel, R., 2005. Nappe stacking resulting from subduction of oceanic and continental lithosphere below Greece, Geology, 33(4), $325-328$.

von Quadt, A. \& Peytcheva, I., 2005. The southern extension of the Srednogorie type upper Cretaceous magmatism in Rila-Western Rhodopes: constraints from isotope-geochronological and geochemical data, in Bulgarian National Conference "GEO-SCIENCES 2005".

von Quadt, A., Peytcheva, I., Sarov, S., Naydenov, K., \& Georgiev, N., 2008. Metamorphic rocks from Dospat area of Western Rhodopes - conventional and in situ U-Pb zircon dat-ing, isotope tracing and correlations, in Bulgarian National Conference "GEOSCIENCES 2008".

von Quadt, A., Peytcheva, I., Sarov, S., \& Liati, A., 2010. Late Cretaceous subduction and magmatism in the Rhodopes: geochronological and isotope-geochemical evidence, in Bulgarian National Conference "GEOSCIENCES 2010". 
Wawrzenitz, N. \& Krohe, A., 1998. Exhumation and doming of the Thasos metamorphic core complex (S Rhodope, Greece): structural and geochronological constraints, Tectonophysics, $285(3-4), 301-332$.

Wiedenbeck, M., Allé, P., Corfu, F., Griffin, W. L., Meier, M., Oberli, F., von Quadt, A., Roddick, J. C., \& Spiegel, W., 1995. Three Natural Zircon Standards for U-Th-Pb, Lu-Hf, Trace Element and REE Analyses, Geostandards Newsletter, 19(1), 1 - 23.

Wijbrans, J. R. \& McDougall, I., 1986. ${ }^{40} \mathrm{Ar} /{ }^{39} \mathrm{Ar}$ dating of white micas from an alpine highpressure metamorphic belt on Naxos (Greece): the resetting of the argon isotopic system, Contributions to Mineralogy and Petrology, 93(2), 187 - 194.

Zervas, S., 1979. Age determination by the $87 \mathrm{Rb} / 87 \mathrm{Sr}$ method of some pegmatites in the area of Lagada (Macedonia, Greece) (in greek), Annales Geologiques des Pays Helleniques, XXX(1), $143-152$. 


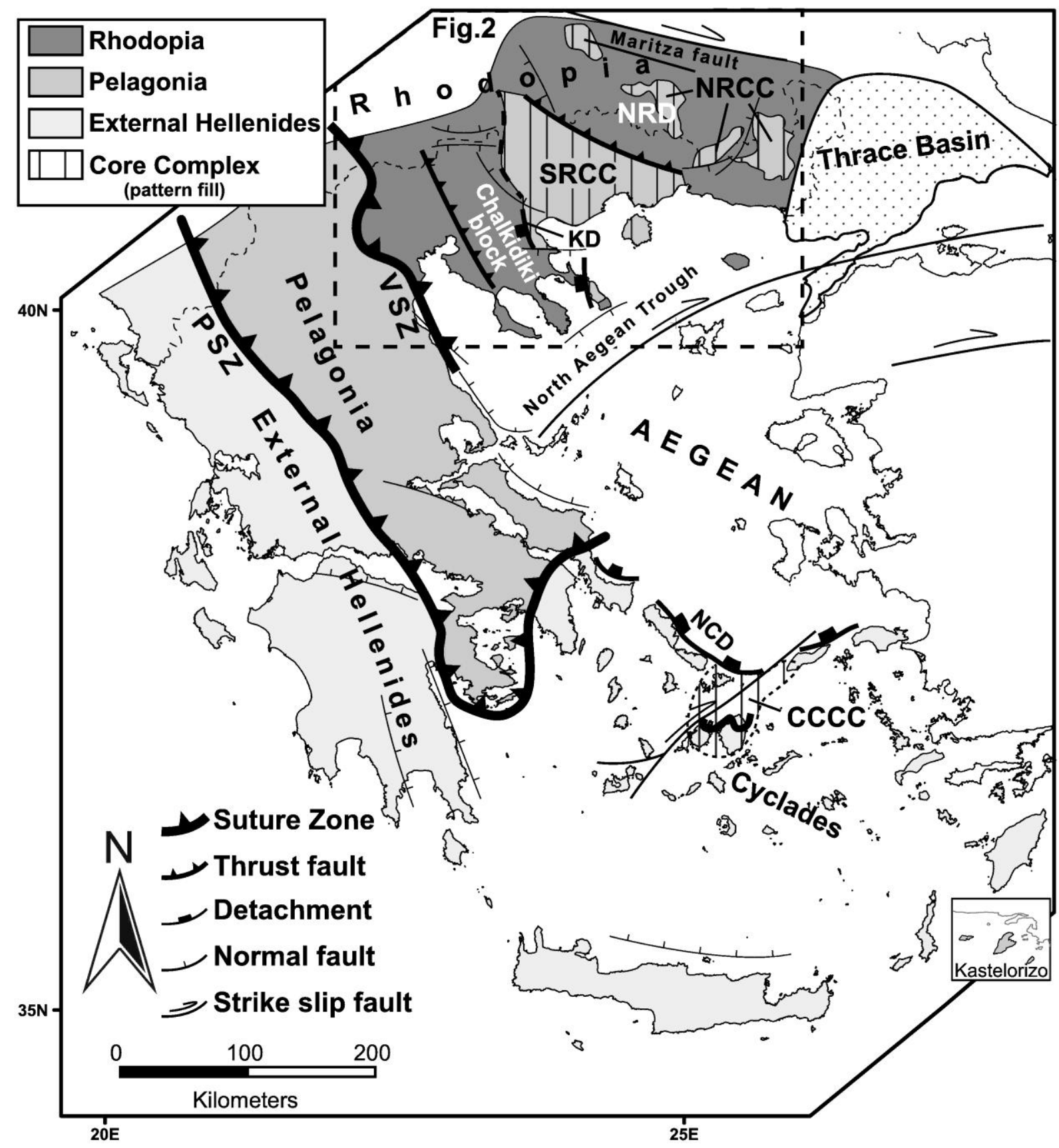

Figure 1 


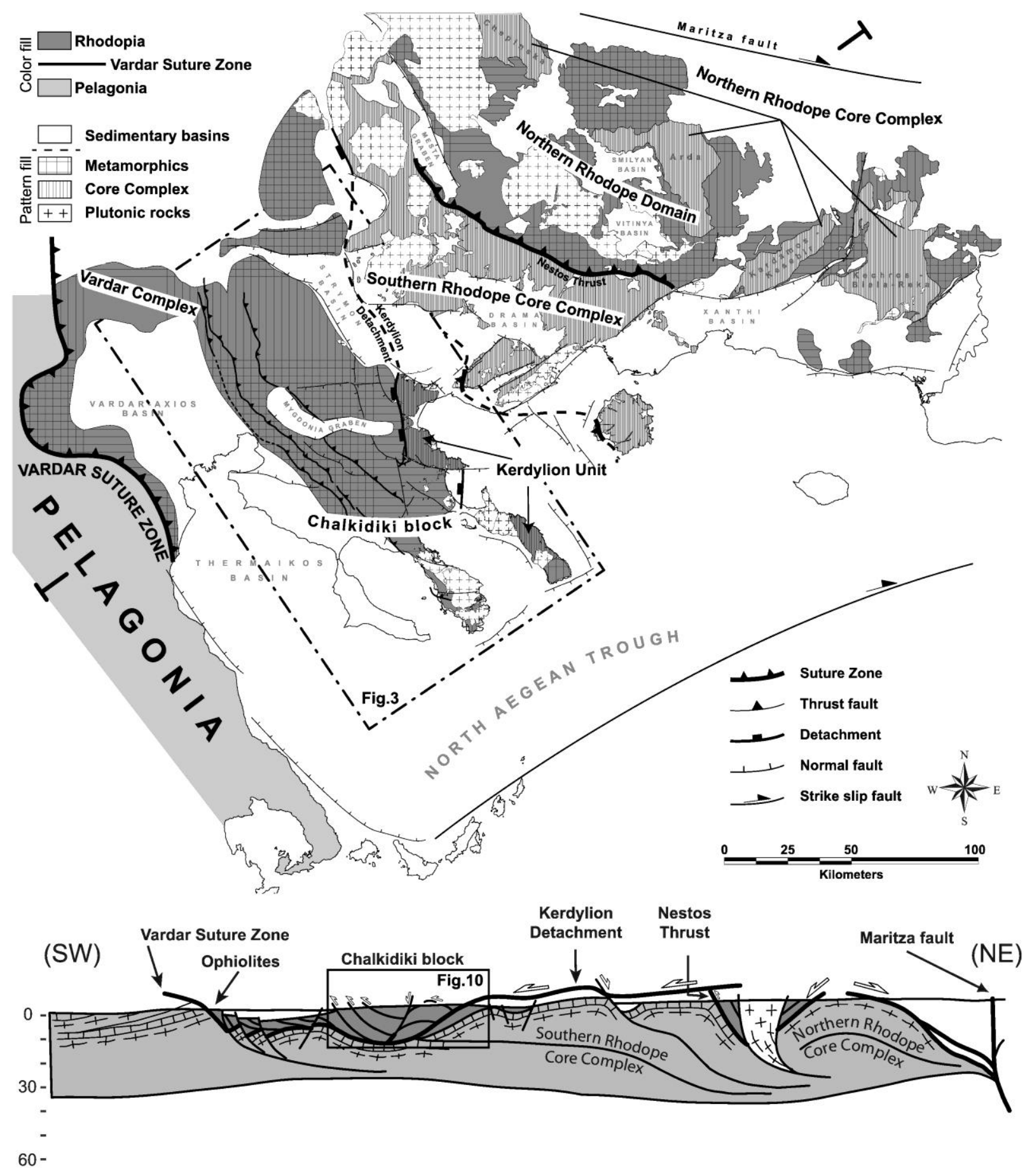

Figure 2 


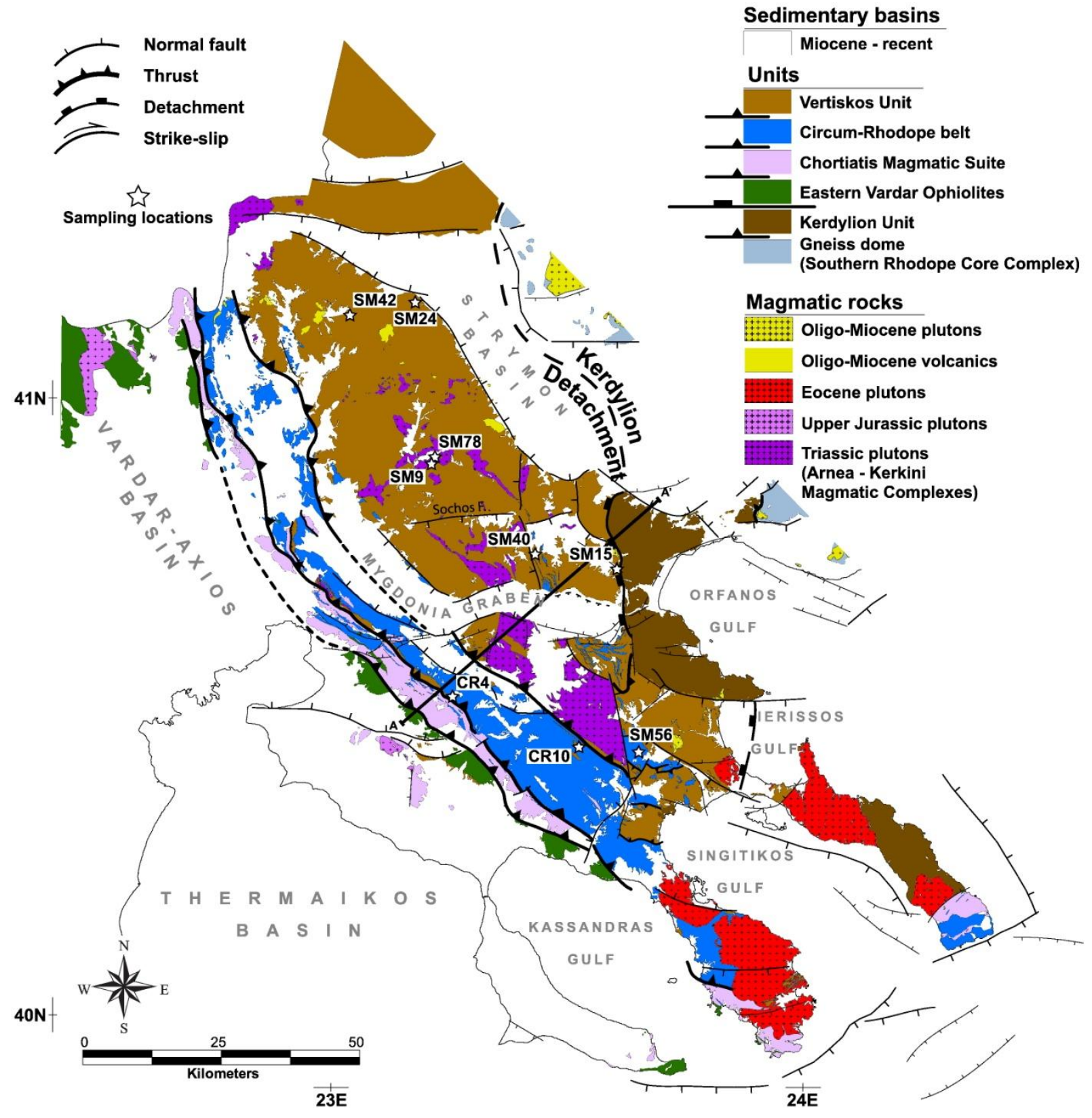

Figure 3 


\section{ACCEPTED MANUSCRIPT}

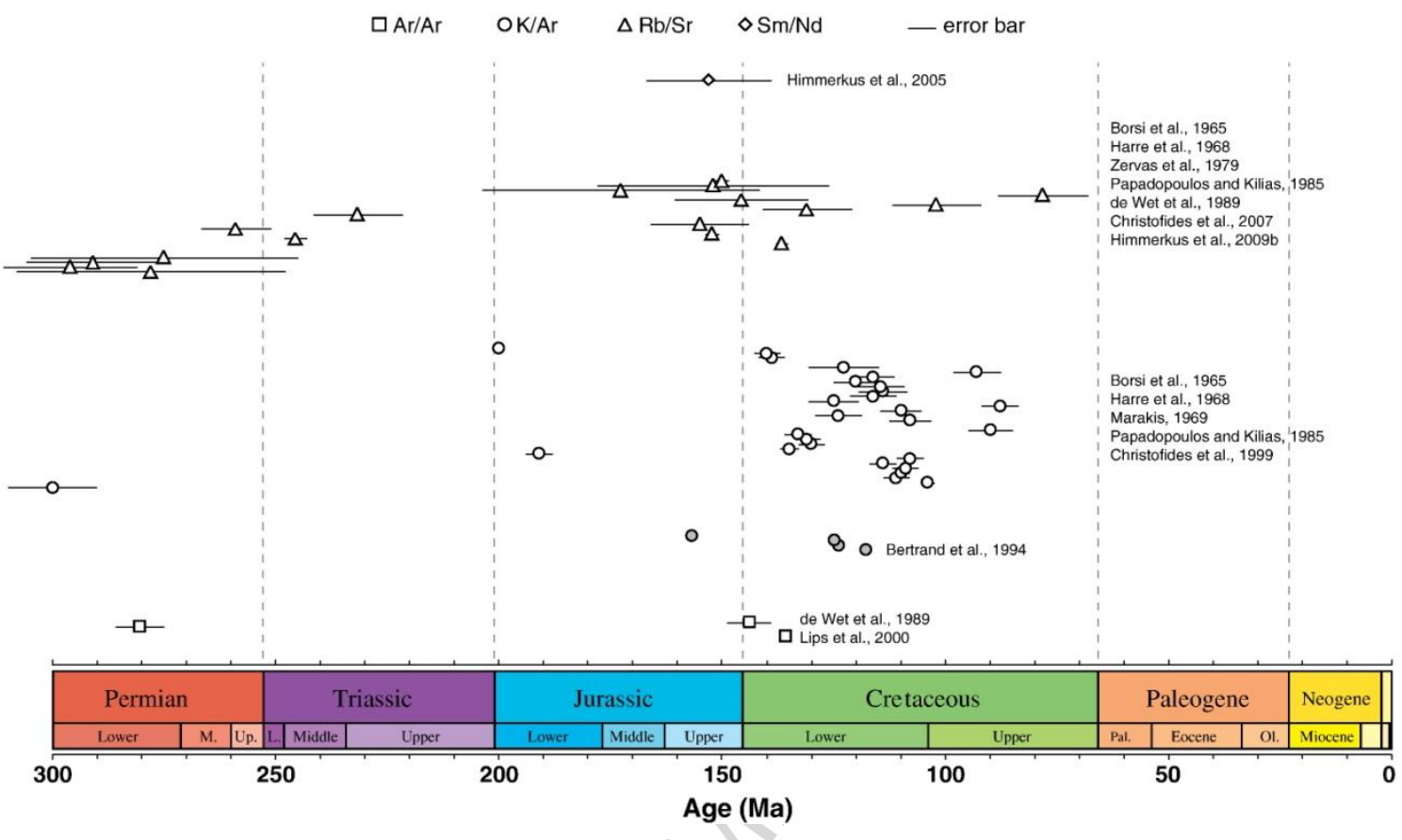

Figure 4 

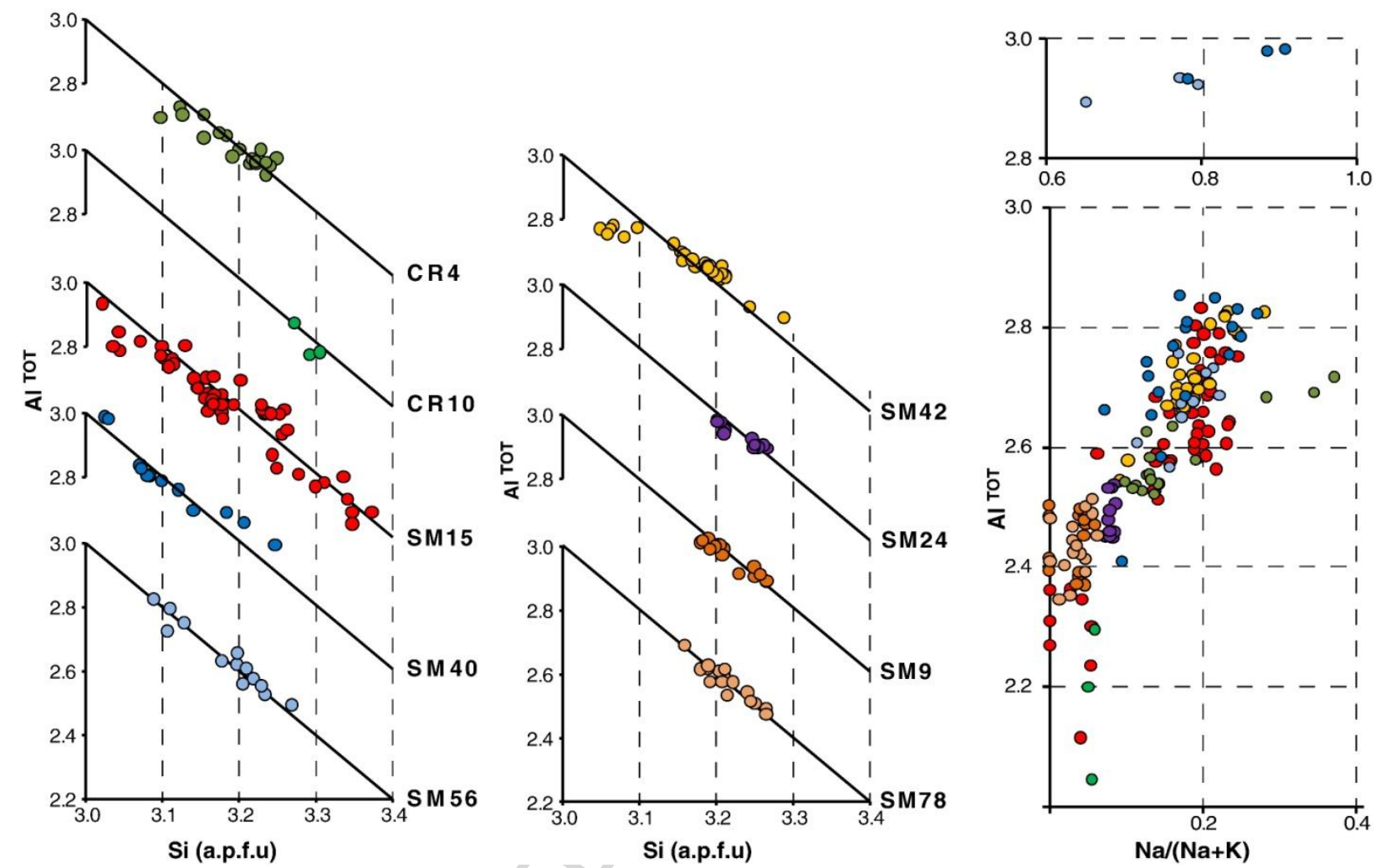

Figure 5 

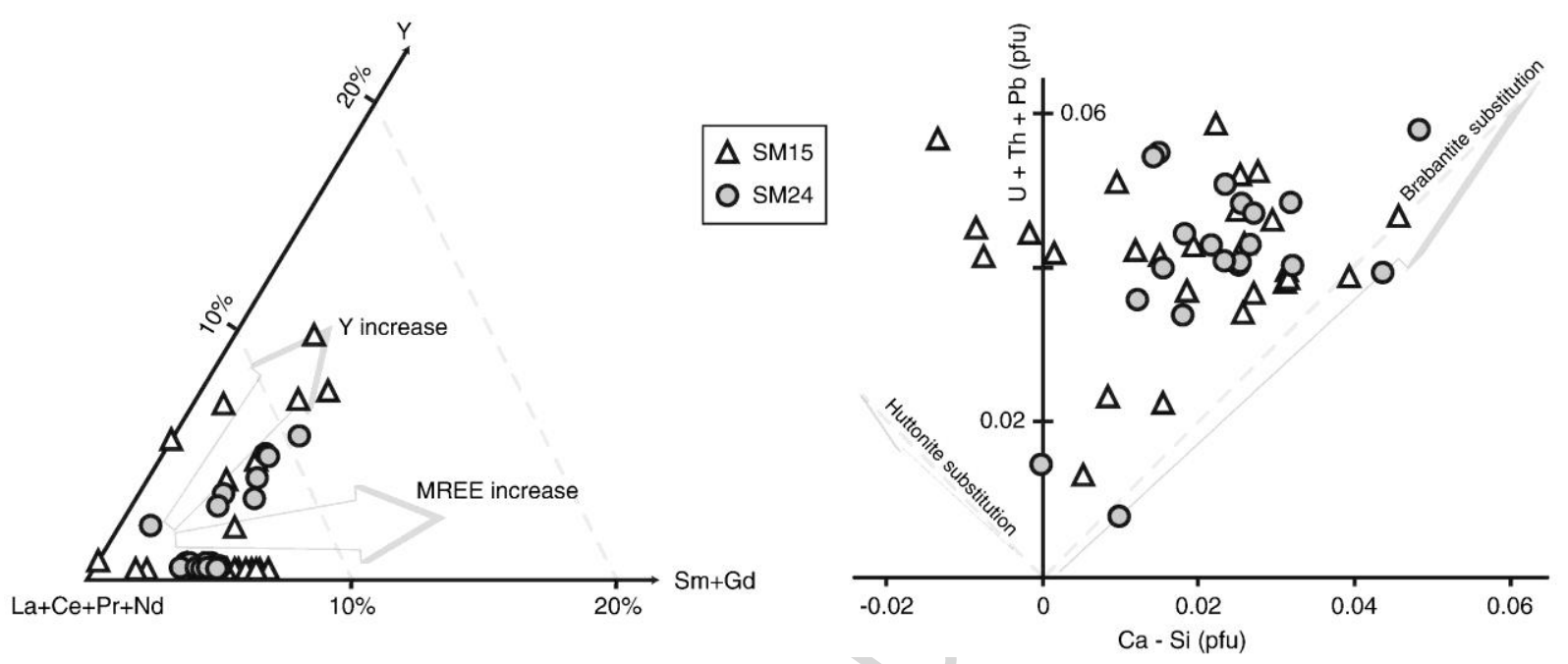

Figure 6 

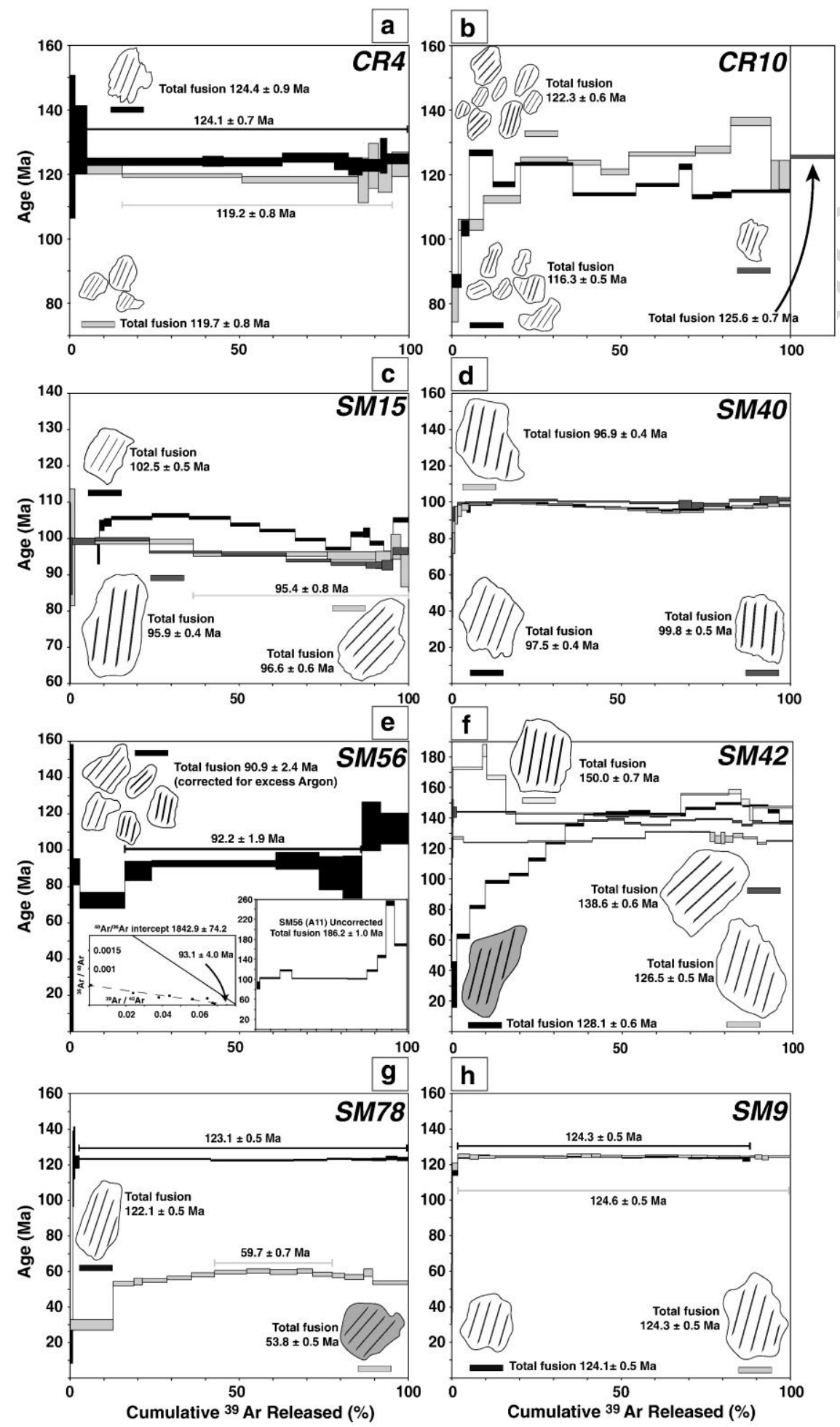

Figure 7 

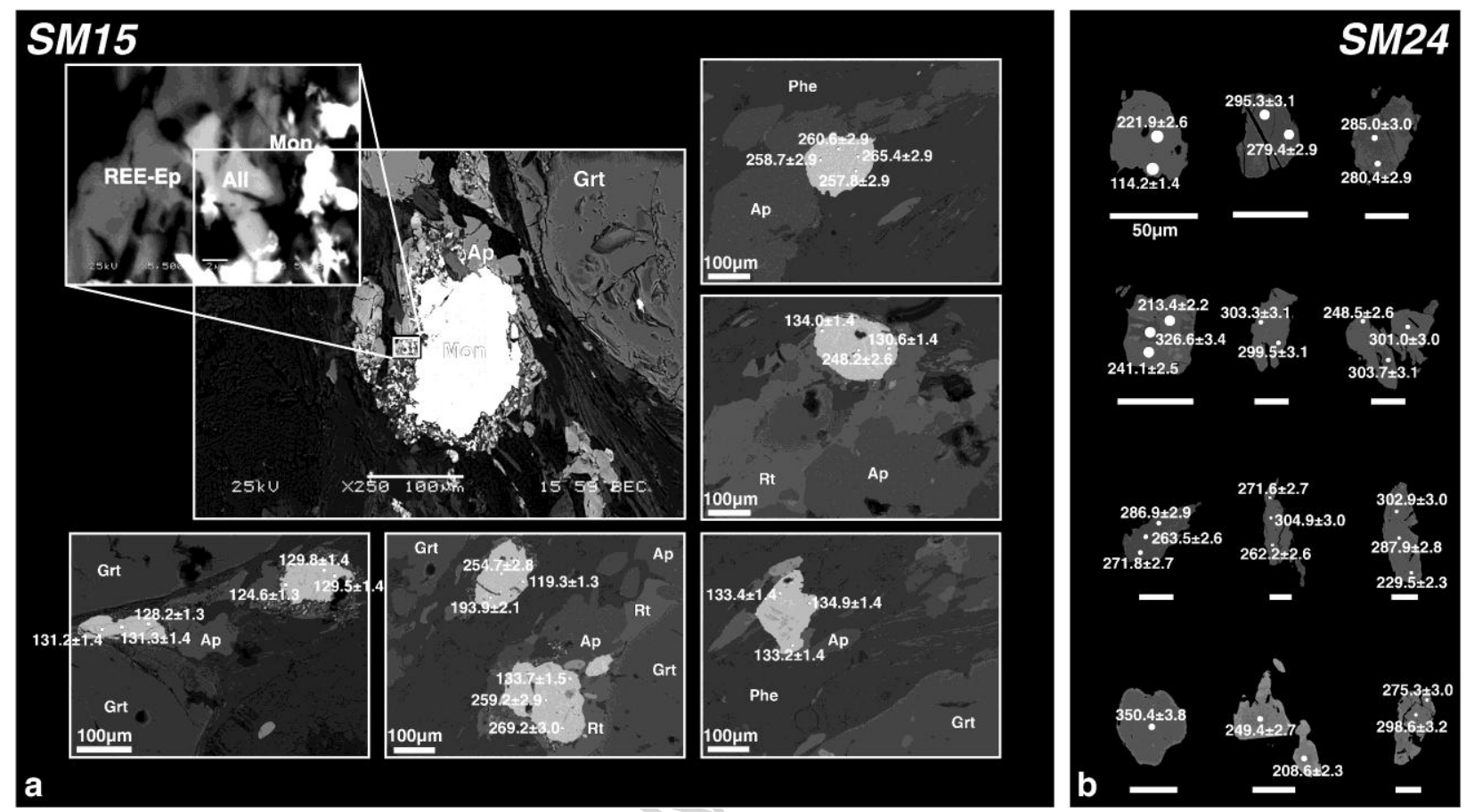

Figure 8 

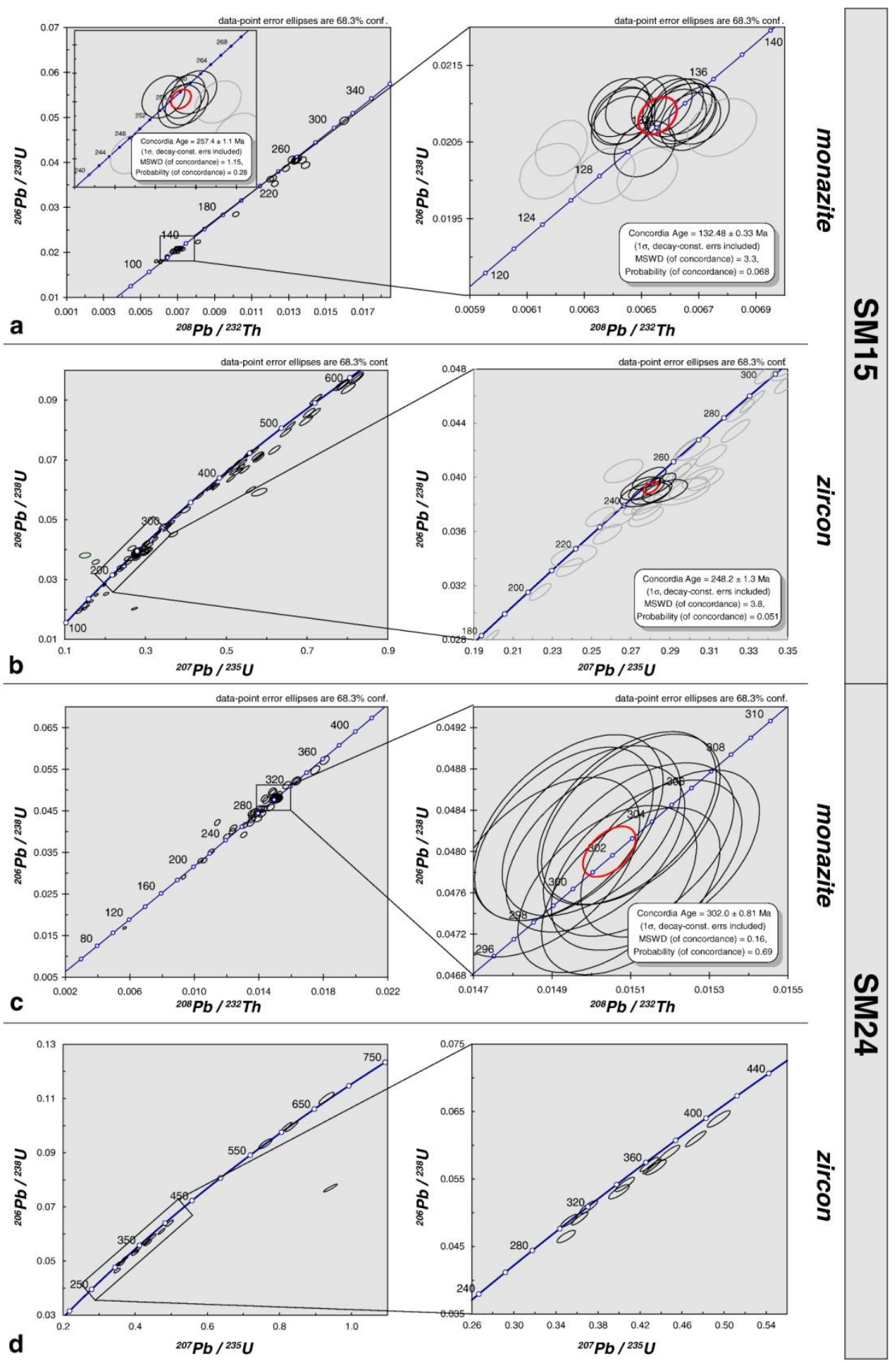

Figure 9 


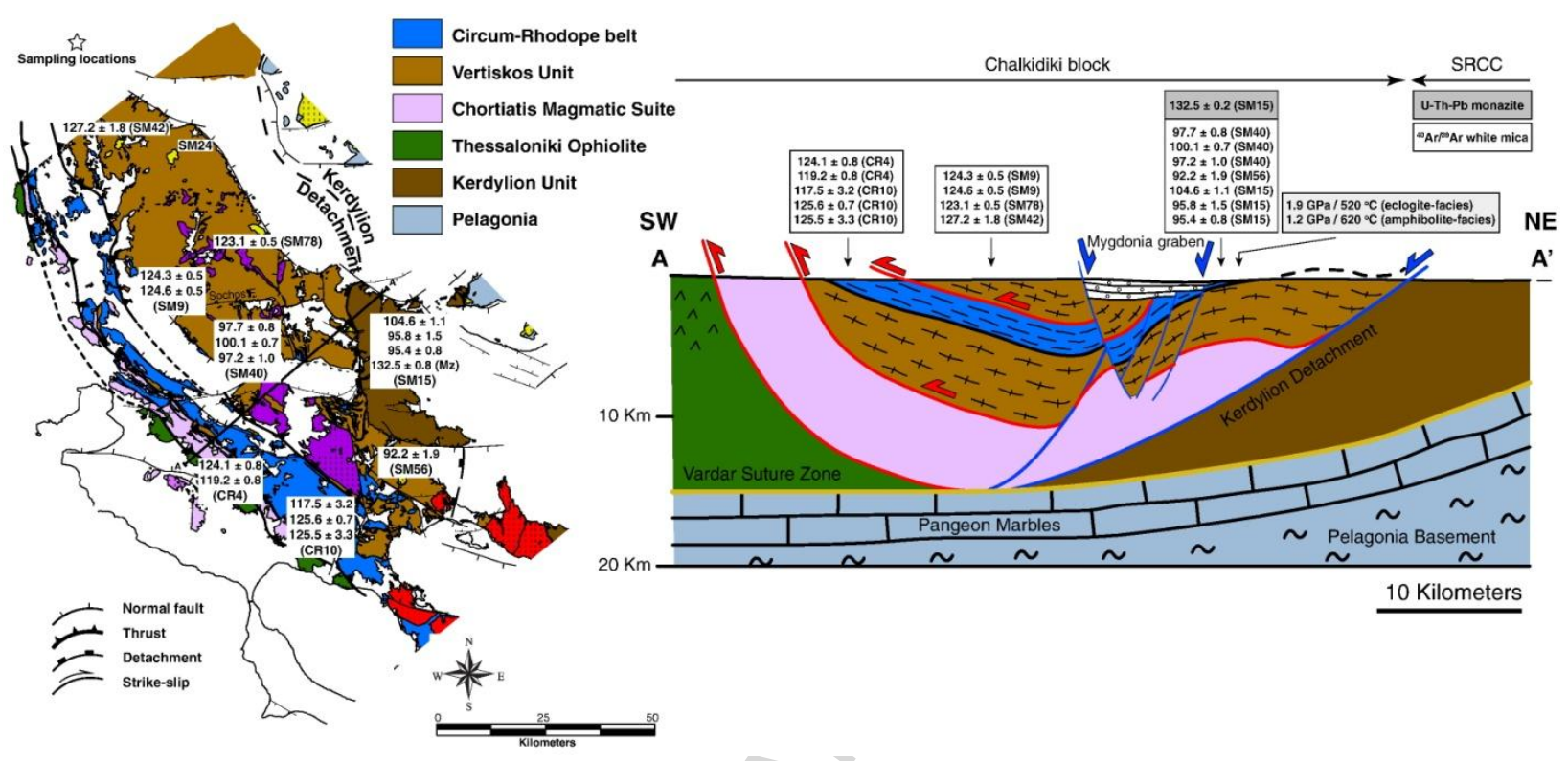

Figure 10 


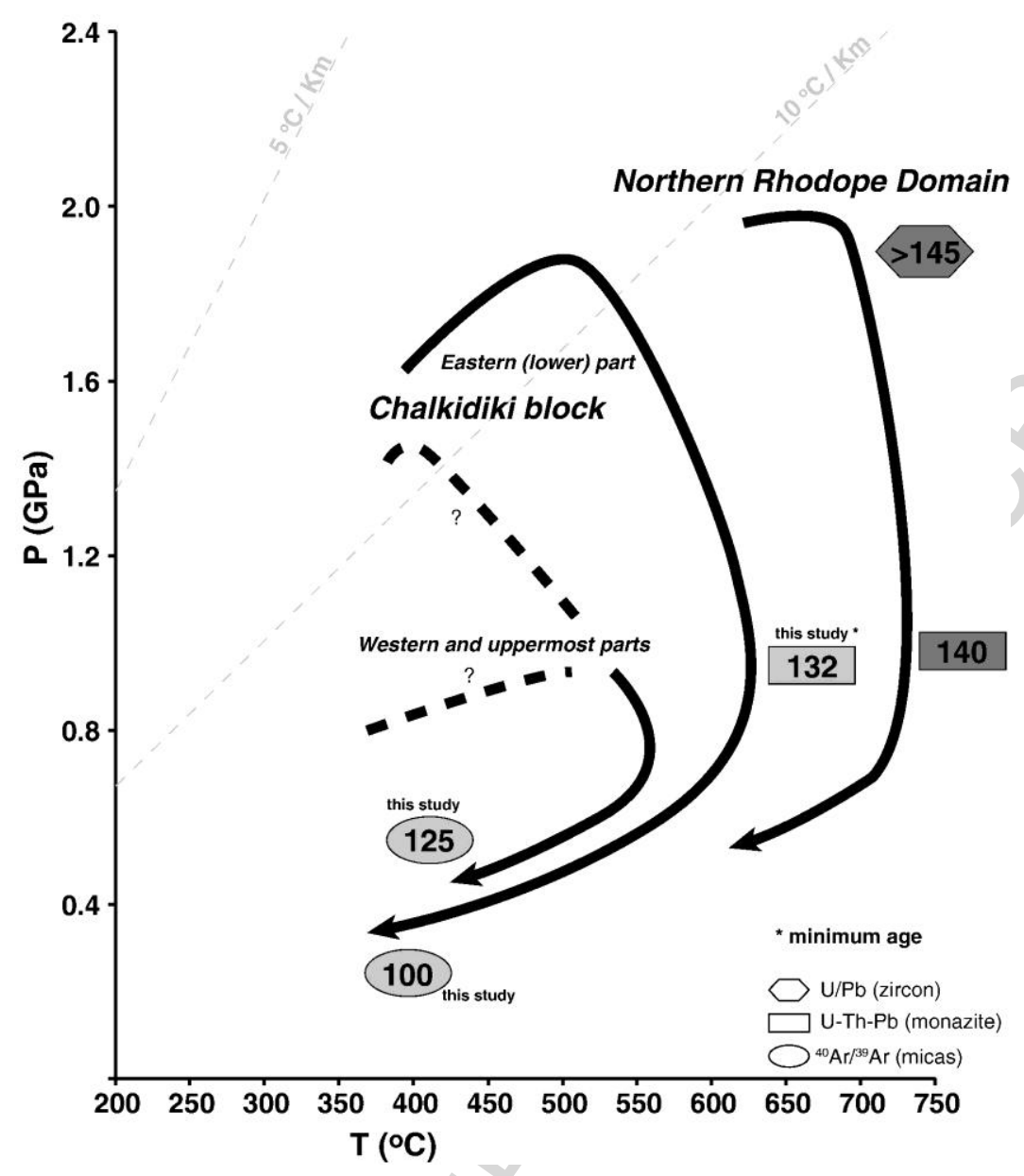

Figure 11 
Table 1. List of samples used for ${ }^{40} \mathrm{Ar} /{ }^{39} \mathrm{Ar}$ and $\mathrm{U}-\mathrm{Th}-\mathrm{Pb}$ geochronology. Mineral abbreviation scheme after Siivola and Schmid (2007).

\begin{tabular}{|c|c|c|c|c|}
\hline Sample & Latitude & Longtitude & Rocktype & Mineral assemblage (major/accessory) \\
\hline \multicolumn{5}{|c|}{ Lower basement-cover complex } \\
\hline \multicolumn{5}{|c|}{ Western part } \\
\hline $\mathrm{CR} 4$ & 40.53 & 23.22 & phyllite & qtz,phg,pg,chl,grt / zrn \\
\hline CR10 & 40.45 & 23.52 & phyllite & qtz,phg,chl / cal,rt,bt \\
\hline \multicolumn{5}{|c|}{ Eastern part } \\
\hline SM15 & 40.73 & 23.61 & schist & $\begin{array}{l}\text { qtz,grt,ky,phg,rt / } \\
\text { st,chl,bt,ilm,ep,zrn,mon,ap,aln }\end{array}$ \\
\hline SM40 & 40.76 & 23.41 & schist & phg,qtz,par,grt,bt,st,chl,ky / mon,zrn,ilm,aln \\
\hline SM56 & 40.44 & 23.65 & schist & phg,qtz,par,grt,bt,chl / zrn \\
\hline \multicolumn{5}{|c|}{ Upper basement slice } \\
\hline \multicolumn{5}{|c|}{ Paragneisses of unknown protolith age } \\
\hline $\mathrm{SM} 24$ & 41.13 & 23.21 & schist & qtz,phg,grt,ky,bt / chl,mon,zrn,ap,rt,ilm \\
\hline SM42 & 41.13 & 23.02 & schist & qtz,phg,grt,bt,ilm,fsp / zrn,rt,chl,mon \\
\hline \multicolumn{5}{|c|}{ Triassic orthogneisses } \\
\hline SM9 & 40.91 & 23.21 & orthogneiss & qtz,phg,fsp,bt / rt,zrn,ap \\
\hline SM78 & 40.90 & 23.21 & orthogneiss & qtz,phg,fsp,bt / rt,zrn,ap \\
\hline
\end{tabular}


Table 2. Representative white mica electron microprobe mineral analyses (in wt \%).

\begin{tabular}{|c|c|c|c|c|c|c|c|c|c|c|c|c|c|}
\hline $\begin{array}{l}\text { sample } \\
\text { rocktype }\end{array}$ & $\begin{array}{c}\text { CR4 } \\
\text { phyllite }\end{array}$ & $\begin{array}{c}\text { CR4 } \\
\text { phyllite }\end{array}$ & $\begin{array}{c}\text { CR10 } \\
\text { phyllite }\end{array}$ & $\begin{array}{l}\text { SM15 } \\
\text { schist }\end{array}$ & $\begin{array}{l}\text { SM15 } \\
\text { schist }\end{array}$ & $\begin{array}{l}\text { SM40 } \\
\text { schist }\end{array}$ & $\begin{array}{l}\text { SM40 } \\
\text { schist }\end{array}$ & $\begin{array}{l}\text { SM56 } \\
\text { schist }\end{array}$ & $\begin{array}{l}\text { SM56 } \\
\text { schist }\end{array}$ & $\begin{array}{c}\text { SM24 } \\
\text { paragneiss }\end{array}$ & $\begin{array}{c}\text { SM24 } \\
\text { paragneiss }\end{array}$ & $\begin{array}{c}\text { SM42 } \\
\text { paragneiss }\end{array}$ & $\begin{array}{c}\text { SM9 } \\
\text { orthogneiss }\end{array}$ \\
\hline mineral & w. mica & w. mica & w. mica & w. mica & w. mica & w. mica & w. mica & w. mica & w. mica & w. mica & w. mica & w. mica & w. mica \\
\hline $\mathrm{SiO}_{2}$ & 47.07 & 48.91 & 49.14 & 47.64 & 46.52 & 46.51 & 48.57 & 46.90 & 48.75 & 48.32 & 48.74 & 46.56 & 47.80 \\
\hline $\mathrm{TiO}_{2}$ & 0.37 & 0.00 & 0.48 & 0.70 & 0.56 & 0.30 & 0.00 & 0.34 & 0.00 & 1.31 & 1.54 & 0.47 & 0.83 \\
\hline $\mathbf{A l}_{2} \mathbf{O}_{3}$ & 32.87 & 32.23 & 29.93 & 34.00 & 34.87 & 36.49 & 31.91 & 36.03 & 32.85 & 32.43 & 32.28 & 35.75 & 31.48 \\
\hline $\mathrm{FeO}(\mathrm{T})$ & 2.10 & 2.32 & 2.46 & 1.04 & 1.18 & 0.91 & 1.63 & 0.67 & 1.17 & 1.33 & 1.38 & 1.01 & 2.48 \\
\hline MnO & 0.03 & 0.00 & 0.00 & 0.00 & 0.10 & 0.00 & 0.00 & 0.00 & 0.00 & 0.00 & 0.00 & 0.00 & 0.00 \\
\hline MgO & 1.46 & 1.68 & 2.27 & 1.28 & 0.71 & 0.67 & 1.83 & 0.73 & 1.70 & 1.03 & 0.99 & 0.75 & 1.52 \\
\hline $\mathrm{CaO}$ & 0.00 & 0.00 & 0.00 & 0.00 & 0.01 & 0.00 & 0.00 & 0.00 & 0.00 & 0.00 & 0.00 & 0.00 & 0.00 \\
\hline $\mathrm{Na}_{2} \mathrm{O}$ & 1.09 & 0.88 & 0.42 & 1.53 & 1.90 & 1.51 & 0.91 & 1.88 & 1.17 & 0.53 & 0.62 & 1.83 & 0.30 \\
\hline $\mathbf{K}_{2} \mathbf{O}$ & 9.72 & 9.56 & 10.14 & 9.32 & 8.85 & 9.00 & 9.91 & 8.45 & 9.74 & 10.89 & 10.83 & 8.70 & 10.98 \\
\hline \multirow[t]{2}{*}{ TOTAL } & 94.70 & 95.58 & 94.84 & 95.51 & 94.70 & 95.39 & 94.76 & 95.00 & 95.38 & 95.84 & 96.38 & 95.07 & 95.39 \\
\hline & [11] O & [11] O & [11] O & [11] O & [11] O & [11] O & [11] O & [11] O & [11] O & [11] O & [11] O & [11] O & [11] O \\
\hline $\mathbf{S i}$ & 3.16 & 3.24 & 3.29 & 3.14 & 3.10 & 3.06 & 3.24 & 3.09 & 3.22 & 3.20 & 3.21 & 3.08 & 3.20 \\
\hline $\mathbf{T i}$ & 0.02 & 0.00 & 0.02 & 0.03 & 0.03 & 0.01 & 0.00 & 0.02 & 0.00 & 0.07 & 0.08 & 0.02 & 0.04 \\
\hline Al & 2.60 & 2.51 & 2.36 & 2.65 & 2.74 & 2.83 & 2.51 & 2.80 & 2.56 & 2.53 & 2.51 & 2.79 & 2.49 \\
\hline $\mathrm{Fe}^{+2}$ & 0.12 & 0.13 & 0.14 & 0.06 & 0.07 & 0.05 & 0.09 & 0.04 & 0.06 & 0.07 & 0.08 & 0.06 & 0.14 \\
\hline Mn & 0.00 & 0.00 & 0.00 & 0.00 & 0.01 & 0.00 & 0.00 & 0.00 & 0.00 & 0.00 & 0.00 & 0.00 & 0.00 \\
\hline Mg & 0.15 & 0.17 & 0.23 & 0.13 & 0.07 & 0.07 & 0.18 & 0.07 & 0.17 & 0.10 & 0.10 & 0.07 & 0.15 \\
\hline $\mathbf{C a}$ & 0.00 & 0.00 & 0.00 & 0.00 & 0.00 & 0.00 & 0.00 & 0.00 & 0.00 & 0.00 & 0.00 & 0.00 & 0.00 \\
\hline
\end{tabular}




\begin{tabular}{c|ccccccccccccc}
$\mathbf{N a}$ & 0.14 & 0.11 & 0.05 & 0.20 & 0.25 & 0.19 & 0.12 & 0.24 & 0.15 & 0.07 & 0.08 & 0.23 & 0.04 \\
$\mathbf{K}$ & 0.83 & 0.81 & 0.87 & 0.78 & 0.75 & 0.76 & 0.84 & 0.71 & 0.82 & 0.92 & 0.91 & 0.73 & 0.94 \\
\hline TOTAL & 7.01 & 6.97 & 6.96 & 6.99 & 7.00 & 6.98 & 6.98 & 6.97 & 6.98 & 6.96 & 6.95 & 6.99 \\
\hline$M g \#$ & 0.55 & 0.56 & 0.62 & 0.69 & 0.52 & 0.57 & 0.67 & 0.66 & 0.74 & 0.58 & 0.56 & 0.57 & 0.52
\end{tabular}


Table 3. Representative monazite electron microprobe analyses (in wt.\%).

\begin{tabular}{|c|c|c|c|c|c|c|c|c|}
\hline $\begin{array}{c}\text { Sample } \\
\text { Rocktype }\end{array}$ & $\begin{array}{l}\text { SM15 } \\
\text { Schist }\end{array}$ & $\begin{array}{l}\text { SM15 } \\
\text { Schist }\end{array}$ & $\begin{array}{l}\text { SM15 } \\
\text { Schist }\end{array}$ & $\begin{array}{l}\text { SM15 } \\
\text { Schist }\end{array}$ & $\begin{array}{c}S M 24 \\
\text { Paragneiss }\end{array}$ & $\begin{array}{c}S M 24 \\
\text { Paragneiss }\end{array}$ & $\begin{array}{c}S M 24 \\
\text { Paragneiss }\end{array}$ & $\begin{array}{c}S M 24 \\
\text { Paragneiss }\end{array}$ \\
\hline $\mathrm{SiO}_{2}$ & 0.39 & 0.27 & 0.66 & 0.00 & 0.48 & 0.31 & 0.65 & 0.34 \\
\hline $\mathrm{TiO}_{2}$ & 0.00 & 0.00 & 0.00 & 0.00 & 0.00 & 0.00 & 0.00 & 0.00 \\
\hline $\mathbf{A l}_{2} \mathbf{O}_{3}$ & 0.00 & 0.00 & 0.00 & 0.00 & 0.00 & 0.00 & 0.00 & 0.00 \\
\hline $\mathrm{Fe}_{2} \mathrm{O}_{3}$ & 0.00 & 0.00 & 0.00 & 0.00 & 0.00 & 0.00 & 0.00 & 0.00 \\
\hline $\mathrm{FeO}$ & 0.00 & 0.00 & 0.00 & 0.00 & 0.00 & 0.00 & 0.00 & 0.00 \\
\hline MnO & 0.00 & 0.00 & 0.00 & 0.00 & 0.00 & 0.00 & 0.00 & 0.00 \\
\hline MgO & 0.00 & 0.00 & 0.00 & 0.00 & 0.00 & 0.00 & 0.00 & 0.00 \\
\hline $\mathrm{CaO}$ & 0.96 & 0.62 & 1.15 & 1.09 & 0.74 & 0.53 & 0.94 & 0.74 \\
\hline $\mathrm{Na}_{2} \mathrm{O}$ & 0.00 & 0.00 & 0.00 & 0.00 & 0.00 & 0.00 & 0.00 & 0.00 \\
\hline $\mathbf{K}_{2} \mathbf{O}$ & 0.00 & 0.00 & 0.00 & 0.00 & 0.00 & 0.00 & 0.00 & 0.00 \\
\hline $\mathbf{P}_{2} \mathbf{O}_{5}$ & 29.73 & 29.68 & 29.69 & 30.09 & 29.53 & 31.49 & 28.99 & 29.55 \\
\hline $\mathbf{Y}_{2} \mathbf{O}_{3}$ & 0.00 & 0.00 & 0.00 & 0.00 & 0.00 & 3.06 & 0.00 & 0.00 \\
\hline $\mathbf{L a}_{2} \mathbf{O}_{3}$ & 12.76 & 12.43 & 12.42 & 13.25 & 13.72 & 13.65 & 12.94 & 13.08 \\
\hline $\mathrm{Ce}_{2} \mathrm{O}_{3}$ & 32.78 & 34.34 & 32.11 & 32.40 & 32.93 & 32.85 & 32.45 & 34.15 \\
\hline $\mathrm{Pr}_{2} \mathrm{O}_{3}$ & 3.00 & 4.23 & 3.77 & 3.45 & 3.23 & 2.68 & 3.60 & 3.43 \\
\hline $\mathrm{Nd}_{2} \mathrm{O}_{3}$ & 11.93 & 12.63 & 11.14 & 11.99 & 12.22 & 10.88 & 11.26 & 11.80 \\
\hline $\mathrm{Sm}_{2} \mathrm{O}_{3}$ & 2.03 & 2.47 & 1.68 & 1.70 & 1.39 & 1.84 & 1.47 & 1.69 \\
\hline $\mathbf{E u}_{2} \mathbf{O}_{3}$ & 0.00 & 0.00 & 0.00 & 0.00 & 0.00 & 0.00 & 0.00 & 0.00 \\
\hline $\mathbf{G d}_{2} \mathbf{O}_{3}$ & 1.28 & 1.55 & 1.30 & 1.06 & 1.50 & 1.61 & 1.15 & 1.60 \\
\hline $\mathrm{PbO}$ & 0.00 & 0.00 & 0.00 & 0.00 & 0.00 & 0.00 & 0.00 & 0.00 \\
\hline $\mathrm{ThO}_{2}$ & 5.35 & 2.53 & 6.63 & 5.26 & 4.01 & 0.88 & 6.04 & 3.78 \\
\hline $\mathbf{U O}_{2}$ & 0.00 & 0.00 & 0.00 & 0.00 & 0.00 & 0.00 & 0.00 & 0.00 \\
\hline \multirow[t]{2}{*}{ Total } & 100.21 & 100.76 & 100.55 & 100.28 & 99.76 & 99.77 & 99.49 & 100.16 \\
\hline & [4] O & [4] O & [4] O & [4] O & [4] O & [4] O & [4] O & [4] O \\
\hline Si & 0.02 & 0.01 & 0.03 & 0.00 & 0.02 & 0.01 & 0.03 & 0.01 \\
\hline $\mathrm{Ti}$ & 0.00 & 0.00 & 0.00 & 0.00 & 0.00 & 0.00 & 0.00 & 0.00 \\
\hline Al & 0.00 & 0.00 & 0.00 & 0.00 & 0.00 & 0.00 & 0.00 & 0.00 \\
\hline $\mathrm{Fe}^{+3}$ & 0.00 & 0.00 & 0.00 & 0.00 & 0.00 & 0.00 & 0.00 & 0.00 \\
\hline $\mathrm{Fe}^{+2}$ & 0.00 & 0.00 & 0.00 & 0.00 & 0.00 & 0.00 & 0.00 & 0.00 \\
\hline$M n$ & 0.00 & 0.00 & 0.00 & 0.00 & 0.00 & 0.00 & 0.00 & 0.00 \\
\hline $\mathrm{Mg}$ & 0.00 & 0.00 & 0.00 & 0.00 & 0.00 & 0.00 & 0.00 & 0.00 \\
\hline $\mathrm{Ca}$ & 0.04 & 0.03 & 0.05 & 0.05 & 0.03 & 0.02 & 0.04 & 0.03 \\
\hline $\mathrm{Na}$ & 0.00 & 0.00 & 0.00 & 0.00 & 0.00 & 0.00 & 0.00 & 0.00 \\
\hline K & 0.00 & 0.00 & 0.00 & 0.00 & 0.00 & 0.00 & 0.00 & 0.00 \\
\hline $\mathbf{P}$ & 0.99 & 0.99 & 0.98 & 1.00 & 0.98 & 1.01 & 0.97 & 0.99 \\
\hline$Y$ & 0.00 & 0.00 & 0.00 & 0.00 & 0.00 & 0.06 & 0.00 & 0.00 \\
\hline La & 0.18 & 0.18 & 0.18 & 0.19 & 0.20 & 0.19 & 0.19 & 0.19 \\
\hline $\mathrm{Ce}$ & 0.47 & 0.49 & 0.46 & 0.46 & 0.47 & 0.46 & 0.47 & 0.49 \\
\hline
\end{tabular}




$\begin{array}{ccccccccc}\text { Pr } & 0.04 & 0.06 & 0.05 & 0.05 & 0.05 & 0.04 & 0.05 & 0.05 \\ \mathbf{N d} & 0.17 & 0.18 & 0.16 & 0.17 & 0.17 & 0.15 & 0.16 & 0.17 \\ \mathbf{S m} & 0.03 & 0.03 & 0.02 & 0.02 & 0.02 & 0.02 & 0.02 & 0.02 \\ \mathbf{E u} & 0.00 & 0.00 & 0.00 & 0.00 & 0.00 & 0.00 & 0.00 & 0.00 \\ \mathbf{G d} & 0.02 & 0.02 & 0.02 & 0.01 & 0.02 & 0.02 & 0.02 & 0.02 \\ \mathbf{P b} & 0.00 & 0.00 & 0.00 & 0.00 & 0.00 & 0.00 & 0.00 & 0.00 \\ \text { Th } & 0.05 & 0.02 & 0.06 & 0.05 & 0.04 & 0.01 & 0.05 & 0.03 \\ \mathbf{U} & 0.00 & 0.00 & 0.00 & 0.00 & 0.00 & 0.00 & 0.00 & 0.00 \\ \text { Total } & 2.00 & 2.01 & 2.00 & 2.00 & 2.00 & 1.99 & 2.00 & 2.00 \\ & & & & & & & & \\ \text { \% Mnz } & 89.78 & 94.19 & 86.99 & 90.75 & 91.51 & 95.54 & 88.31 & 92.32 \\ \text { \% Hutt } & 1.52 & 1.05 & 2.52 & 0.00 & 1.88 & 1.28 & 2.50 & 1.29 \\ \text { \% Brab } & 8.70 & 4.77 & 10.49 & 9.25 & 6.61 & 3.18 & 9.19 & 6.38\end{array}$


Table 4. Summary of the obtained ${ }^{40} \mathrm{Ar} /{ }^{39} \mathrm{Ar}$ ages.

\begin{tabular}{|c|c|c|c|c|c|c|c|c|c|c|c|c|c|c|}
\hline Sample & Mineral & $\begin{array}{c}\# \\
\text { grains }\end{array}$ & Size & $\begin{array}{l}\text { Latit } \\
\text { ude }\end{array}$ & $\begin{array}{l}\text { Longti } \\
\text { tude }\end{array}$ & $\begin{array}{c}\text { Rockt } \\
\text { ype }\end{array}$ & Mineralogy & $\begin{array}{c}\text { Total } \\
\text { gas age }\end{array}$ & $\begin{array}{c}\text { Plateau } \\
\text { age }\end{array}$ & $\begin{array}{l}{ }^{\%} \\
{ }^{39} \mathrm{Ar}\end{array}$ & $\begin{array}{l}\text { Preferre } \\
\text { d Age }\end{array}$ & $\begin{array}{c}\text { Inverse } \\
\text { isochron age }\end{array}$ & $\begin{array}{l}{ }^{40} \mathrm{Ar} /{ }^{36} \mathrm{Ar} \\
\text { intercept }\end{array}$ & $\begin{array}{l}\text { MS } \\
\text { WD }\end{array}$ \\
\hline \multicolumn{15}{|c|}{$\begin{array}{l}\text { Lower basement-cover complex } \\
\text { (western part) }\end{array}$} \\
\hline CR4 & White mica & 1 & $\begin{array}{c}\sim 750 \\
\mu \mathrm{m}\end{array}$ & $\begin{array}{c}40.5 \\
3\end{array}$ & 23.22 & $\begin{array}{l}\text { phyllit } \\
\text { e }\end{array}$ & $\begin{array}{l}\mathrm{qtz}+\mathrm{w} \cdot \mathrm{mica}+\mathrm{grt}+ \\
\text { opaques } \pm \mathrm{bt}\end{array}$ & $\begin{array}{l}124.38 \\
\pm 0.90\end{array}$ & $\begin{array}{l}124.08 \\
\pm 0.74\end{array}$ & 100 & $\begin{array}{l}124.08 \pm \\
0.74\end{array}$ & $\begin{array}{l}123.50 \pm \\
1.24\end{array}$ & $\begin{array}{l}398.25 \pm \\
157.72\end{array}$ & 0.76 \\
\hline CR4 & White mica & 3 & $\begin{array}{c}\sim 450 \\
\mu \mathrm{m}\end{array}$ & $\begin{array}{c}40.5 \\
3\end{array}$ & 23.22 & $\begin{array}{l}\text { phyllit } \\
\text { e }\end{array}$ & $\begin{array}{l}\mathrm{qtz}+\text { w.mica }+\mathrm{grt}+ \\
\text { opaques } \pm \mathrm{bt}\end{array}$ & $\begin{array}{l}119.63 \\
\pm 0.79\end{array}$ & $\begin{array}{l}119.21 \\
\pm 0.82\end{array}$ & $\begin{array}{c}79.6 \\
2\end{array}$ & $\begin{array}{c}119.21 \pm \\
0.82\end{array}$ & $\begin{array}{c}118.93 \pm \\
0.97\end{array}$ & $\begin{array}{l}324.00 \pm \\
23.80\end{array}$ & 1.68 \\
\hline CR10 & White mica & 6 & $\begin{array}{l}\sim 300- \\
420 \mu \mathrm{m}\end{array}$ & $\begin{array}{c}40.4 \\
5\end{array}$ & 23.52 & $\begin{array}{l}\text { phyllit } \\
\text { e }\end{array}$ & $\begin{array}{l}\mathrm{qtz}+\text { w.mica }+ \\
\quad \text { opaques }\end{array}$ & $\begin{array}{l}116.29 \\
\pm 0.53\end{array}$ & 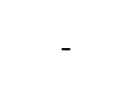 & - & $\begin{array}{l}117.54 \pm \\
3.23\end{array}$ & $\begin{array}{c}118.33 \pm \\
3.40\end{array}$ & $\begin{array}{l}131.80 \pm \\
76.60\end{array}$ & $>100$ \\
\hline CR10 & White mica & 1 & $\begin{array}{c}\sim 420 \\
\mu \mathrm{m}\end{array}$ & $\begin{array}{c}40.4 \\
5\end{array}$ & 23.52 & $\begin{array}{l}\text { phyllit } \\
\mathrm{e}\end{array}$ & $\begin{array}{l}\mathrm{qtz}+\text { w.mica }+ \\
\text { opaques }\end{array}$ & $\begin{array}{l}125.59 \\
\pm 0.70\end{array}$ & - & - & $\begin{array}{c}125.59 \pm \\
0.70\end{array}$ & - & - & - \\
\hline CR10 & White mica & 8 & $\begin{array}{c}\sim 450 \\
\mu \mathrm{m}\end{array}$ & $\begin{array}{c}40.4 \\
5\end{array}$ & 23.52 & $\begin{array}{l}\text { phyllit } \\
\text { e }\end{array}$ & $\begin{array}{c}\mathrm{qtz}+\text { w.mica }+ \\
\text { opaques }\end{array}$ & $\begin{array}{l}122.27 \\
\pm 0.64\end{array}$ & - & - & $\begin{array}{l}125.46 \pm \\
3.25\end{array}$ & $\begin{array}{l}119.02 \pm \\
8.12\end{array}$ & $\begin{array}{c}3830.70 \pm \\
9743.50\end{array}$ & 2.43 \\
\hline \multicolumn{15}{|c|}{$\begin{array}{l}\text { Lower basement-cover complex } \\
\text { (eastern part) }\end{array}$} \\
\hline SM40 & White mica & 1 & $\begin{array}{l}\sim 750 \\
\mu \mathrm{m}\end{array}$ & $\begin{array}{c}40.7 \\
6\end{array}$ & 23.41 & & $\begin{array}{l}\text { w.mica }+ \text { grt }+ \text { st }+ \\
\mathrm{qtz}+\mathrm{rt}+\mathrm{chl} \pm \mathrm{bt}\end{array}$ & $\begin{array}{c}97.46 \pm \\
0.42\end{array}$ & - & - & $\begin{array}{l}97.70 \pm \\
0.79\end{array}$ & $94.75 \pm 1.27$ & $\begin{array}{c}742.2 \pm \\
425.9\end{array}$ & $\begin{array}{c}15.4 \\
7\end{array}$ \\
\hline SM40 & White mica & 1 & $\begin{array}{c}\sim 700 \\
\mu \mathrm{m}\end{array}$ & $\begin{array}{c}40.7 \\
6\end{array}$ & 23.41 & & $\begin{array}{l}\mathrm{w} \cdot \mathrm{mica}+\mathrm{grt}+\mathrm{st}+ \\
\mathrm{qtz}+\mathrm{rt}+\mathrm{chl} \pm \mathrm{bt}\end{array}$ & $\begin{array}{c}99.77 \pm \\
0.49\end{array}$ & - & - & $\begin{array}{c}100.10 \pm \\
0.71\end{array}$ & $99.33 \pm 1.15$ & $\begin{array}{l}819.80 \pm \\
593.10\end{array}$ & 2.41 \\
\hline SM40 & White mica & 1 & $\begin{array}{l}\sim 1000 \\
\mu \mathrm{m}\end{array}$ & $\begin{array}{c}40.7 \\
6\end{array}$ & 23.41 & hist & $\begin{array}{l}\text { w.mica }+ \text { grt }+ \text { st }+ \\
\mathrm{qtz}+\mathrm{rt}+\mathrm{chl} \pm \mathrm{bt}\end{array}$ & $\begin{array}{c}96.89 \pm \\
0.42\end{array}$ & - & - & $\begin{array}{c}97.20 \pm \\
1.0\end{array}$ & $94.82 \pm 1.89$ & $\begin{array}{c}1365.0 \pm \\
837.70\end{array}$ & $\begin{array}{c}11.2 \\
3\end{array}$ \\
\hline SM56 & White mica & 5 & $\begin{array}{c}\sim 550 \\
\mu \mathrm{m}\end{array}$ & $\begin{array}{c}40.4 \\
4\end{array}$ & 23.65 & schist & $\begin{array}{c}\mathrm{w} \cdot \mathrm{mica}+\mathrm{qtz}+\mathrm{grt}+ \\
\mathrm{bt}+\mathrm{st}\end{array}$ & $\begin{array}{l}90.89 \pm \\
2.38\end{array}$ & $\begin{array}{c}92.17 \pm \\
1.88\end{array}$ & $\begin{array}{c}69.9 \\
5\end{array}$ & $\begin{array}{c}92.17 \pm \\
1.88\end{array}$ & $93.14 \pm 3.97$ & $\begin{array}{l}1842.90 \pm \\
74.2\end{array}$ & 6.12 \\
\hline \multicolumn{15}{|c|}{$\begin{array}{l}\text { Upper basement slice } \\
\text { (paragneisses) }\end{array}$} \\
\hline SM42 & Biotite & 1 & $\begin{array}{c}\sim 1500 \\
\mu \mathrm{m}\end{array}$ & $\begin{array}{c}41.1 \\
3\end{array}$ & 23.02 & schist & $\underset{\text { grt }}{\mathrm{w} \cdot \operatorname{mica}}+\mathrm{bt}+\mathrm{qtz}+$ & $\begin{array}{l}128.11 \\
\pm 0.62\end{array}$ & $\begin{array}{l}142.49 \\
\pm 0.78\end{array}$ & $\begin{array}{c}29.8 \\
9\end{array}$ & $\begin{array}{c}144.94 \pm \\
2.48\end{array}$ & $\begin{array}{c}141.38 \pm \\
2.31\end{array}$ & $\begin{array}{l}313.30 \pm \\
34.70\end{array}$ & 0.36 \\
\hline SM42 & White mica & 1 & $\begin{array}{l}\sim 1200 \\
\mu \mathrm{m}\end{array}$ & $\begin{array}{c}41.1 \\
3\end{array}$ & 23.02 & schist & $\underset{\text { grt }}{\text { w.mica }+ \text { bt }+q t z+}$ & $\begin{array}{l}150.03 \\
\pm 0.65\end{array}$ & - & - & - & $\begin{array}{c}141.84 \pm \\
9.04\end{array}$ & $\begin{array}{c}1022.3 \pm \\
815.3\end{array}$ & $>100$ \\
\hline SM42 & White mica & 1 & $\begin{array}{c}\sim 1500 \\
\mu \mathrm{m}\end{array}$ & $\begin{array}{c}41.1 \\
3\end{array}$ & 23.02 & schist & $\underset{\text { grt }}{\text { w.mica }+ \text { bt }+ \text { qtz }+}$ & $\begin{array}{l}138.62 \\
\pm 0.58\end{array}$ & - & - & $\begin{array}{c}137.53 \pm \\
1.02\end{array}$ & $\begin{array}{c}137.48 \pm \\
1.09\end{array}$ & $\begin{array}{l}308.80 \pm \\
63.10\end{array}$ & $\begin{array}{c}28.6 \\
9\end{array}$ \\
\hline SM42 & White mica & 1 & $\begin{array}{c}\sim 1500 \\
\mu \mathrm{m}\end{array}$ & $\begin{array}{c}41.1 \\
3\end{array}$ & 23.02 & schist & $\begin{array}{c}\mathrm{w} \cdot \operatorname{mica}+\mathrm{bt}+\mathrm{qtz}+ \\
\mathrm{grt}\end{array}$ & $\begin{array}{l}126.51 \\
\pm 0.54\end{array}$ & - & - & $\begin{array}{c}127.21 \pm \\
1.84\end{array}$ & $\begin{array}{c}127.84 \pm \\
2.24\end{array}$ & $\begin{array}{c}280.80 \pm \\
9.80\end{array}$ & 4.6 \\
\hline SM15 & White mica & 1 & $\sim 750$ & 40.7 & 23.61 & schist & w. mica + grt + ky + & 102.50 & - & - & $104.57 \pm$ & $106.19 \pm$ & $262.10 \pm$ & 5.48 \\
\hline
\end{tabular}




\begin{tabular}{|c|c|c|c|c|c|c|c|c|c|c|c|c|c|c|}
\hline & & & $\mu \mathrm{m}$ & 3 & & & $\mathrm{qtz}+\mathrm{chl}$ & \pm 0.45 & & & 1.16 & 1.33 & 103.40 & \\
\hline SM15 & White mica & 1 & $\begin{array}{c}\sim 2000 \\
\mu \mathrm{m}\end{array}$ & $\begin{array}{c}40.7 \\
3\end{array}$ & 23.61 & schist & $\begin{array}{l}\text { w. mica }+ \text { grt }+ \text { ky }+ \\
\text { qtz }+ \text { chl }\end{array}$ & $\begin{array}{c}95.94 \pm \\
0.43\end{array}$ & - & - & $\begin{array}{l}95.79 \pm \\
1.52\end{array}$ & $94.16 \pm 1.53$ & $\begin{array}{c}374.20 \pm \\
47.40\end{array}$ & $\begin{array}{c}32.7 \\
6\end{array}$ \\
\hline SM15 & White mica & 1 & $\begin{array}{l}\sim 2000 \\
\mu \mathrm{m}\end{array}$ & $\begin{array}{c}40.7 \\
3\end{array}$ & 23.61 & schist & $\begin{array}{l}\text { w. mica }+ \text { grt }+ \text { ky }+ \\
\text { qtz }+ \text { chl }\end{array}$ & $96.63 \pm$ & & - & $\begin{array}{l}95.40 \pm \\
0.79\end{array}$ & $94.73 \pm 2.94$ & $\begin{array}{c}334.80 \pm \\
166.40\end{array}$ & 2.03 \\
\hline \multicolumn{15}{|c|}{$\begin{array}{l}\text { Upper basement slice (Triassic } \\
\text { orthogneisses) }\end{array}$} \\
\hline SM9 & White mica & 1 & $\begin{array}{c}\sim 600 \\
\mu \mathrm{m}\end{array}$ & $\begin{array}{c}40.9 \\
1\end{array}$ & 23.21 & $\begin{array}{l}\text { orthog } \\
\text { neiss }\end{array}$ & $\begin{array}{l}\text { w. mica }+ \text { bt }+ \text { qtz }+ \\
\text { K-fel }+ \text { plag }\end{array}$ & $\begin{array}{l}124.06 \\
\pm 0.50\end{array}$ & $\begin{array}{l}124.25 \\
\pm 0.52\end{array}$ & $\begin{array}{c}86.2 \\
4\end{array}$ & $\begin{array}{c}124.25 \pm \\
0.52\end{array}$ & $\begin{array}{c}124.24 \pm \\
0.53\end{array}$ & $\begin{array}{l}299.5 \pm \\
39.5\end{array}$ & 1.86 \\
\hline SM9 & White mica & 1 & $\begin{array}{l}\sim 1000 \\
\mu \mathrm{m}\end{array}$ & $\begin{array}{c}40.9 \\
1\end{array}$ & 23.21 & $\begin{array}{l}\text { orthog } \\
\text { neiss }\end{array}$ & $\begin{array}{l}\text { w. mica }+ \text { bt }+ \text { qtz }+ \\
\text { K-fel + plag }\end{array}$ & $\begin{array}{l}124.32 \\
\pm 0.50\end{array}$ & $\begin{array}{l}124.60 \\
\pm 0.50\end{array}$ & $\begin{array}{c}98.1 \\
3\end{array}$ & $\begin{array}{c}124.60 \pm \\
0.50\end{array}$ & $\begin{array}{c}124.60 \pm \\
0.51\end{array}$ & $\begin{array}{c}302.70 \pm \\
52.4\end{array}$ & 1.48 \\
\hline SM78 & Biotite & 1 & $\begin{array}{l}\sim 750 \\
\mu \mathrm{m}\end{array}$ & $\begin{array}{c}40.9 \\
0\end{array}$ & 23.21 & $\begin{array}{l}\text { orthog } \\
\text { neiss }\end{array}$ & $\begin{array}{l}\text { w. mica }+ \text { bt }+ \text { qtz }+ \\
\text { K-fel }+ \text { plag }\end{array}$ & $\begin{array}{c}53.82 \pm \\
0.51\end{array}$ & $\begin{array}{c}56.65 \pm \\
0.65\end{array}$ & 34.8 & $\begin{array}{l}56.65 \pm \\
0.65\end{array}$ & - & - & - \\
\hline SM78 & White mica & 1 & $\begin{array}{l}\sim 1000 \\
\mu \mathrm{m}\end{array}$ & $\begin{array}{c}40.9 \\
0\end{array}$ & 23.21 & $\begin{array}{l}\text { orthog } \\
\text { neiss }\end{array}$ & $\begin{array}{l}\text { w. mica }+ \text { bt }+ \text { qtz }+ \\
\text { K-fel }+ \text { plag }\end{array}$ & $\begin{array}{l}122.11 \\
\pm 0.53\end{array}$ & $\begin{array}{l}123.05 \\
\pm 0.54\end{array}$ & $\begin{array}{c}97.2 \\
8\end{array}$ & $\begin{array}{c}123.05 \pm \\
0.54\end{array}$ & $\begin{array}{c}122.95 \pm \\
0.69\end{array}$ & $\begin{array}{c}305.20 \pm \\
39.8\end{array}$ & 1.91 \\
\hline
\end{tabular}




\section{Highlights}

We present new geochronology data from the southwestern part of the Rhodope

The study area (Chalkidiki block) retains a rather rich Cretaceous isotopic record

Monazite breakdown at $\sim 132 \mathrm{Ma}$ provides a minimum age for the amphibolite-facies event

Amphibolite-facies overprint predates the end of thrusting in the area

Cooling and arrival at shallow crustal levels occurred by the end of Early Cretaceous 